\title{
Entrepreneurial Identity
}

Identity refers to the meanings that individuals attach to themselves (Gecas 1982) and is often understood as the answer to the question "Who am I?" (Stryker and Burke 2000). Answering this question allows people to fulfill a basic need to be distinct from others, which is important for psychological (Fromkin and Snyder 1980) and physical (Markus and Kitayama 1991) health. Nevertheless, although the notion that entrepreneurs are different and distinct is a key topic in entrepreneurship studies (e.g., Baker and Nelson 2005; Yli-Renko et al. 2001) and founding and growing a venture may fulfill the psychological need to be unique (Teal and Carroll 1999) and therefore to develop a unique selfidentity, doing so may thwart the need to feel belonging (Ashforth and Mael 1989; Tajfel 2010). An unmet need for belonging can lead to feeling isolated (Brewer 1991); this feeling can negatively influence the individual's physical and psychological well-being (Leonardelli and Brewer 2001). In this chapter, we develop a framework for entrepreneurs' dealing with multiple micro-identities (Ashforth et al. 2000; Pratt and Forman 2000) and specify entrepreneurs' strategies to achieve an "ideal" balance between belongingness and distinctiveness (Shepherd and Haynie 2009a). We also explore how individuals can lose their work identities and the role of entrepreneurship in identity recovery and reconstruction.

(C) The Author(s) 2018

D. A. Shepherd, H. Patzelt, Entrepreneurial Cognition, https://doi.org/10.1007/978-3-319-71782-1_5 


\section{DisTinCTIVEnESS}

As just mentioned, individuals have a psychological need to feel unique and different from others (Brewer and Pickett 1999; Hornsey and Jetten 2004; Cantor et al. 2002). This feeling of uniqueness is the basis for developing a sense of distinction from others that plays a key role in the development and sustenance of identity (Brewer 1991; Fromkin and Snyder 1980). ${ }^{1}$ Empirical studies have found that distinguishing oneself from others serves as the foundation for the construction of a unique identity (Teal and Carroll 1999). Moreover, a perceived lack of distinctiveness appears to prompt people to behave in ways that differentiate themselves from referent groups (Tajfel and Turner 1979a, b). This differentiation in turn helps them more clearly define their identities (Turner 1987). As an example, Vignoles et al. (2000) emphasized studies illustrating the prominence of distinctiveness at the identity level, arguing that (1) individuals can memorize information more effectively if it helps them to illustrate how they are different from others (Leyens et al. 1997), (2) groups are seen as being more diverse if the evaluator belongs to the group (Brewer 1993; Park and Rothbart 1982), (3) feelings of intense similarity to other individuals are linked to negative emotions (Fromkin and Snyder 1980), (4) individuals feel a greater sense of identification with groups that are distinct (Brewer and Pickett 1999), and (5) individuals tend to view themselves as less like others than others are to themselves (Codol 1984, 1987).

While the search for distinctiveness has been linked to the motivation to enhance one's self-esteem (Abrams and Hogg 1988), theoretical work (Brewer 1991) and empirical studies (Brewer et al. 1993; Vignoles et al. 2000) have shown that the need for distinctiveness is a "universal human motive" (Brewer and Pickett 1999) enabling self-definition or comparative appraisal of people's identity (Brewer 1991: 478) and that it is separate from self-esteem (Brewer 1991). Thus, we suggest that distinctiveness plays a central role in developing a meaningful sense of an entrepreneurial identity and therefore a notion of who one is as an individual (Vignoles et al. 2000).

\section{BELONGING}

While people pursue distinctiveness, theory has suggested that doing so could come at the expense of fulfilling the need to belong (Baumeister and Leary 1995; Brewer 1991). According to Baumeister and Leary, the need to 
belong is a "powerful, fundamental, and extremely pervasive motivation" (1995: 1). The majority of work on social identity has centered on the advantages of inclusiveness - namely, to be a member of a relevant in-group. Being a member of a group meets the need to belong and is embodied in a desire to develop and preserve long-lasting attachments to other people (Baumeister and Leary 1995). While a number of perspectives have described the benefits of inclusion within a group, the most prominent perspectives have been social identity theory (Tajfel and Turner 1979a, b, 1986) and self-categorization theory (Oakes et al. 1994).

Social identity theory (Tajfel and Turner 1979a, b, 1986) proposes that people are motivated to interpret groups they are a member of favorably as a way to improve their own feelings of self-worth. In addition, work has shown that with more identification with an out-group (i.e., a group that is distinct from the mainstream), his or her perceptions of the mainstream group become more negative (Gramzow and Gaertner 2005). A great deal of work has shown that people often go to extremes to employ group membership in such a manner. Many psychologists, for instance, see the 1999 tragedy at Columbine High School-where two marginalized, outcast students fired on others in their class-as a powerful (even though rare) example of the potential mental consequences stemming from feelings of isolation, rejection, and not belonging. In line with social identity theory, self-categorization theory argues that the pervasiveness of an individual's social identity depends on his or her comparison with others. Indeed, research on self-categorization theory has shown that the importance of a person's social identity emerges from the specific comparisons with others in a social environment (Oakes et al. 1994).

Ultimately, there is substantial evidence showing that people have a strong need to belong and that they behave in a way that this need becomes satisfied. The feeling of belonging appears to be a strong human driver (Baumeister and Leary 1995). Said differently, individuals generate positive emotions from enhanced belongingness (McAdams and Bryant 1987; McAdams 1985) and negative emotions from reduced belongingness (Leary 1990). These negative emotions have been associated with loneliness and anxiety (Tice and Baumeister 1990)—negative emotions that can diminish one's physical and psychological health.

The studies discussed above stress a potential tradeoff in fulfilling psychological needs related to individuals' self-identity. Scholars argue that maintaining distinctiveness is essential for individuals to develop self-identity, yet feeling a sense of belonging and identifying with social groups are basic 
human motivations. Thus, for entrepreneurs distinctiveness appears to reduce belongingness and vice versa (Brewer 1991: 478). We will challenge this notion later.

\section{Optimal Distinctiveness Theory}

Optimal distinctiveness theory argues that people want to be affiliated with groups that enable them to optimally balance their belongingness need and the distinctiveness need (Brewer 1991, 1993). Studies have proposed an inverted U-shaped association between distinctiveness and its advantages (Brewer and Pickett 1999; Brewer and Weber 1994). These studies have argued that this association is caused by the conflict between the need for "differentiation of the self from others" and a need for "inclusion of the self into larger social collectives," which counteract each other (Brewer 1993: 3; Vignoles et al. 2000: 339). Optimal distinctiveness theory is in line with Fromkin and Snyder's (1980) theories of uniqueness. Fromkin and Snyder suggested that a moderate level of distinctiveness is the most acceptable and that both very high and very low levels of distinctiveness are the worst for the individual. Optimal distinctiveness theory, created by Brewer (1991), has been "restricted to the discussion of distinctiveness at the level of the group membership." Extending this notion, Brewer and Gardner (1996) applied the same logic to self-representation at the individual and interpersonal levels. This application proposes that the conflicting assimilation and differentiation needs become manifest at the level of the individual in terms of similarity and uniqueness (Vignoles et al. 2000: 340).

\section{The Identity Distinctiveness of ENTREPRENEURIAL INDIVIDUALS}

An entrepreneurial role generally enables people to meet their distinctiveness need in ways that are in line with the theoretical and empirical findings discussed above. This role provides people with autonomy (e.g. Akande 1994; Boyd and Gumpert 1983; Kuratko and Hodgetts 1995) that enables them to have more influence in their venture's development and, more generally, more control over their lives (Kolvereid 1996; Longenecker et al. 1988). Entrepreneurs can situate their ventures in relation to other ventures (and maybe even other entrepreneurs) in a way that maximizes distinctiveness (Guth and Ginsberg 1991; Lumpkin and 
Dess 1996; Naman and Slevin 1993), and they can build hurdles to imitation that help uphold their own and their venture's distinctiveness (Yip 1982). Although a conventional strategy view would see such behavior as competitive maneuvering and the attempt to enhance one's position in the market, social identity theory suggests that these behaviors also differentiate entrepreneurs from a potential "out-group." This differentiation increases entrepreneurs' notion of the self as being something that is different and unique (Teal and Carroll 1999).

Moreover, compared to more traditional careers, the "freedom" associated with an entrepreneurial role provides a great deal of control over and feedback for the advancement of one's self-identity. In other words, the distinctiveness characteristic of the entrepreneurial process, together with the array of actions and behaviors individuals undertake to meet entrepreneurial ends (e.g., creating a new venture, exploiting a new opportunity), offers these people a range of possibilities to distinguish themselves from other people. Narratives of new venture founders illustrated that some people see "the enterprise in terms of personal growth or fulfillment." Such people believe that "life would not have been complete without proving one had the ability to successfully start a business" (Bruno et al. 1992: 297). In addition, Cova and Svanfeldt (1993) contended that some business founders "create a product that flows from their own internal desires and needs. They create primarily to express subjective conceptions of beauty, emotion, or some aesthetic ideal" (297). Overall, entrepreneurs appear to have substantial opportunities to undertake differentiation activities that align well with their desire to fulfill their need for a unique notion of self.

Scholars have been particularly interested in what makes entrepreneurs distinct from other individuals. Teachers of entrepreneurship classes tend to center their instruction on teaching students to "think outside the box" or to "color outside the lines" since most believe these actions will lead to success in the entrepreneurial context. Researchers explore how entrepreneurs are different from others in terms of their knowledge (Shane 2000), personality (Korunka et al. 2003), motivation (Naffziger et al. 1994), and cognition (Busenitz and Barney 1997). Given our interest in difference as being essential to entrepreneurial behavior and action (and constituting the basis for entrepreneurs' fulfillment of their distinctiveness needs), it is crucial to concurrently think about existing studies suggesting that when individuals distinguish themselves as entrepreneurs, they may not be fulfilling their belongingness needs. In turn, these unmet feelings for belongingness can ultimately diminish individuals' psychological health. 
For instance, some evidence has suggested that founders often put relationships within their personal environment including their family at risk (Ufuk and Ozgen 2001) and tend to feel isolated (Hannafey 2003), lonely (Akande 1994; Gumpert and Boyd 1984) and chronically stressed (Akande 1994). Research has shown that these types of feelings result in increased problems for one's physical well-being (Buttner 1992; Ufuk and Ozgen 2001), psychological well-being (Jamal and Badawi 1995; Naughton 1987; Eden 1975), and satisfaction at work (Buttner 1992; c.f. Naughton 1987). Gumpert and Boyd (1984), for instance, reported that a little more than half of 210 small business owner-managers explained that they "frequently feel a sense of loneliness" and experienced higher stress. The authors attributed the feelings of being lonely to the specific role of entrepreneurs. For instance, many of these individuals responded that they did not have a confidant with whom they could share their major worries, that the intense time requirements associated with business foundation and management isolated them from other people, and that "there's this distance you have to maintain as [owner] manager" (Gumpert and Boyd 1984: 20).

These empirical findings and anecdotes illustrate the possible dark side of entrepreneurship. Yet, founders may vary in the extent to which they experience the dark side. For example, many new ventures are started by an entrepreneurial team (Ucbasaran et al. 2003; Breugst et al. 2015; Breugst and Shepherd 2017; Klotz et al. 2014). Members of this founding team unite to make shared decisions to reach collective venture goals (West 2007) and form team spirit (Lechler 2001). Thus, team members may help fulfill entrepreneurs' belongingness needs and reduce the dark side of entrepreneurship.

Even within entrepreneurial teams, however, one individual typically emerges as the "lead entrepreneur" (Ensley et al. 2000). This structure is often necessary because without some kind of formalizing responsibilities and roles as well as putting someone in charge, the success of a venture is likely to decline (Sine et al. 2006; Stinchcombe 1965). Increased formalization structurally differentiates the lead entrepreneur from other founding team members, which can sometimes lead to conflict and negative interactions between the team's members (Stinchcombe 1965). For instance, Boyd and Gumpert (1983) showed that more than two-thirds of founders who started a venture with partners eventually dissolved their founder teams. Regardless of the distinct role of the lead entrepreneur and 
potential conflict among team members, founding team members likely satisfy part of the individual entrepreneur's need to belong.

We argue that while an entrepreneurial role may fulfill people's need for distinctiveness, the need for belonging is often left unmet, thus ultimately diminishing psychological health. Thus, entrepreneurs who cannot find the right "balance" between distinctiveness and belonging may experience the dark side of entrepreneurship and the negative effects that result from it (see Kets de Vries 1985). Consider the following as an example:

When Daniel C. chose to abandon his 20-year career as a corporate executive and acquire a small structural steel company, he assumed that his prime concerns would be financing the venture and marketing his wares. Certainly these have been challenges, but they paled beside the unexpected demon that surfaced in his new life and for which he was totally unprepared. Its name, for a want of a better, is loneliness. Daniel reflects: "I'd never thought about loneliness before because I'd never met it. In corporate life, there was always someone to share ideas with-my boss or another colleague. They knew what I was saying because they had been there. . . . Now it seems I have no one. Sure, there is an association of structural steel people, but they are my competition. I learned early on that pricing talk is resolutely avoided at association meetings, but even if we don't talk about prices, there are tensions between us simply because we're competitors." . . . To his surprise, Daniel realized that his new role aggravated the headaches and the ulcer that were his usual signs of stress. Daniel's feelings and experience are common among small-company owners [Based on a survey of 450 small business CEOs]. (Gumpert and Boyd 1984: 18)

The next section introduces our framework to clarify the association between belonging and distinctiveness when entrepreneurs (try to) manage the borders separating their micro-identities (see Shepherd and Haynie 2009a).

\section{Entrepreneurs' Optimal Distinctiveness and Psychological Health}

Research usually view people as psychologically healthy when their life is "congruent or meshing with deeply held values that are holistically or fully engaged" (Ryan and Deci 2001: 146). Specifically, optimal distinctiveness theory proposes that medium levels of distinctiveness lead to psychological health. The association is illustrated in Fig. 5.1, where the Y-axis represents 


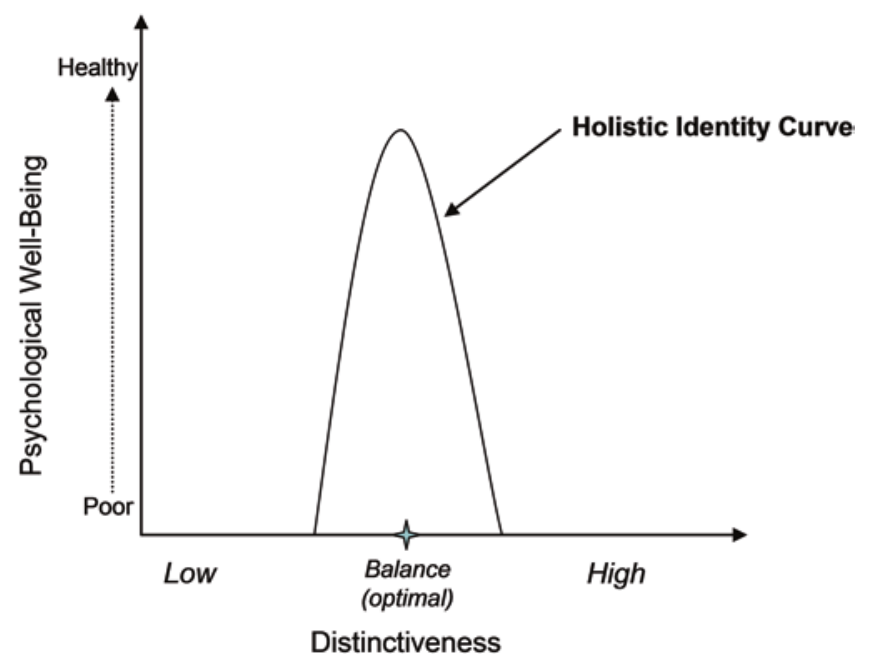

Fig. 5.1 Optimal distinctiveness for an entrepreneuring individual's identity

psychological well-being, the $\mathrm{X}$-axis represents the distinctiveness level, and the curve represents the individual's psychological well-being at different distinctiveness levels. As the figure shows, at low distinctiveness levels (far left), a specific identity offers minimal distinctiveness, so the person shows low psychological well-being. His or her psychological well-being improves with growing distinctiveness until an optimum is reached. After that point, further growing distinctiveness (going right on the $\mathrm{X}$-axis) leads to decreased well-being (due to lower belongingness levels). The upper point of the inverted-U curve signifies this optimum for a particular person and represents the point at which belonging and distinctiveness are well-balanced and there are maximum levels of psychological well-being and health.

For entrepreneurs, the question then becomes whether they can "reshape" their psychological well-being curve to lessen the tradeoff between belonging and distinctiveness. By lessening this tradeoff, entrepreneurs may be able to counteract the implications stemming from the dark side of their entrepreneurial career. To begin to address this issue, my (Dean) colleague and I (Shepherd and Haynie 2009a) integrated the notion of "balance" from optimal distinctiveness theory with studies proposing that people can manage several micro-identities (Ashforth et al. 2000; Pratt and Foreman 2000). Based on this integration, we created a framework to 


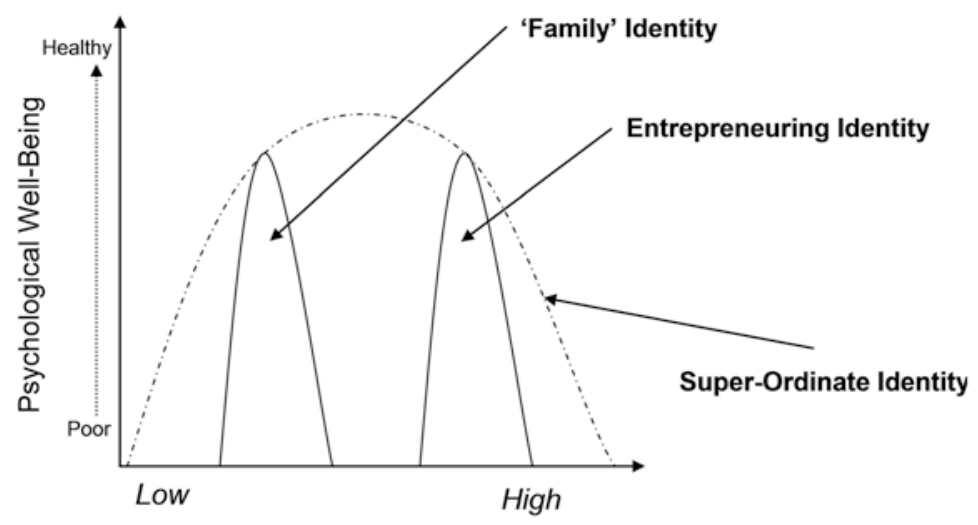

Distinctiveness

Fig. 5.2 Micro-identities and the 'super-ordinate' identity

understand how entrepreneurs can optimally balance belonging and being distinct and at the same time pursue the highly distinctive role identity associated with being a founder. We argued that through the maintenance and management of various micro-identities, entrepreneurs can develop a superordinate identity curve. This super-ordinate identity is a holistic representation of a founder's various micro-identities. Some micro-identities may be associated with belonging and others with distinctiveness, which can help mitigate the tradeoff between the two (Shepherd and Haynie 2009a). This relationship is shown in Fig. 5.2.

Entrepreneurs' micro-identities can be defined by the degree to which they maintain multiple role identities (Greenhaus and Powell 2006). Overall, the number of micro-identities a particular person maintains depends on the number of role identities that he or she incorporates when constructing an overall self-identity (the super-ordinate identity curve). While an entrepreneurial identity is itself likely formed from various microidentities, this added complexity is unnecessary for model development.

Individuals define their identities by the peripheral and central traits characteristic of a specific role (Ashforth et al. 2000: 475). A person may define his or her "entrepreneurial identity" as encompassing a set of central (e.g., strategic orientation, commitment to opportunity, control of resources [Brown et al. 2001]) and peripheral attributes, which together form this person's entrepreneurial identity. ${ }^{2}$ This same person may also see 
his or her "parent" role identity as encompassing a set of central (e.g., role model, protector) and peripheral (e.g., repair person, kids' taxi, etc.) traits, which in sum form the parenthood role identity. All micro-identities have their own curve describing the distinctiveness- well-being relationship, with the maximum of the inverted- $U$ curve representing the best balancing of distinctiveness and belonging with respect to the particular microidentity. The optimal distinctiveness when an individual enacts an entrepreneurial identity differs from the optimal distinctiveness level when that same person enacts other micro-identities. This optimum is also different from an entrepreneur's super-ordinate identity curve (if he or she has more than one micro-identity) as we will outline in more detail below. As an example, the distinctiveness need is more likely to be fulfilled by a person's entrepreneurial identity than by his or her parent identity.

There are boundaries between each of these micro-identities, also known as identity boundaries, or the "physical, temporal, emotional, cognitive, and/or relational limits that define entities [identities] as separate from one another" (Ashforth et al. 2000: 474). An identity boundary may, for example, be defined by a building: once the person enters his or her workplace, that person takes on the identity associated with his or her vocation. Yet, identity boundaries can also be less tangible (e.g., than a building) and more cognitive in nature. Consider a founder who gets a phone call from a business partner while driving. Even though he or she may be heading to the mountains for a weekend getaway, the business call requires an identity transition defined by the person's entrepreneur microidentity boundary. Although we detail the characteristics that define identity boundaries later, it is important to note here that entrepreneurs who maintain only one identity aligning to their ventures are likely less psychologically healthy than entrepreneurs who additionally maintain microidentities related to belongingness.

Entrepreneurs likely differ in the number of micro-identities they have, and these micro-identities are fairly invariant over time. There is also likely to be variance in the weight entrepreneurs assign to their distinct microidentities (as they are a part of one's holistic self-identity) in terms of meeting their personal distinctiveness and belongingness needs. For example, a founder may have various micro-identities that indicate belongingnesssuch as being a family member, sports team member, or church goer-but may only try to fulfill the need for belonging through one (or a few) of those micro-identities (Oswald and Suter 2004; Stewart 2003). 
Entrepreneurs' choice of strategies for managing identities will influence the degree to which various micro-identities channel both distinctiveness and belongingness (and therefore improved psychological health). An identity-management strategy's effectiveness hinges on how one's various microidentities are separated and interact. However, the challenges associated with managing identity (so as to maximize psychological well-being) lie in effectively transitioning between micro-identities - namely, switching from one identity to another so one can "psychologically (and where relevant, physically) exit one role and enter another" (Ashforth et al. 2000: 477). The idea of transitioning between identity boundaries is often viewed as a psychological transaction cost (see Ortona and Scacciati 1992). High psychological costs of leaving one identity and entering another lead to higher costs to one's psychological well-being. Two micro-identity-management strategies - compartmentalization and integration - have implications for a person's psychological well-being via an individual's distinct entrepreneurial identity.

\section{Compartmentalization and Integration as Strategies FOR Micro-IDEnTity Management}

Compartmentalization is a strategy used to maintain an identity that indicates distinctiveness (i.e., their entrepreneurial identity) and one that indicates belonging, choosing between the micro-identities at various times and in multiple situations (Shepherd and Haynie 2009a). Entrepreneurs using a compartmentalization strategy rarely switch between microidentities in order to manage boundaries, specifically to reduce the boundary transition costs. For instance, a founder may also be a father or mother, thus having a parenting identity that addresses his or her need for belonging (Oswald and Suter 2004). Using a strategy of compartmentalization to manage his or her micro-identities, this entrepreneur separates his or her entrepreneurial role from non-work roles by taking on one identity after the other through intermittent transitions. With this approach, the individual is able to internalize his or her micro-identity as an entrepreneur while at work and then switch to other identities (e.g., father/mother, friend, athlete, etc.) when outside work.

A compartmentalization strategy does not alter the shape of the curve of the entrepreneurial identity; rather, it adds an additional curve representing the entrepreneur's non-work micro-identity. In the example, we use two 


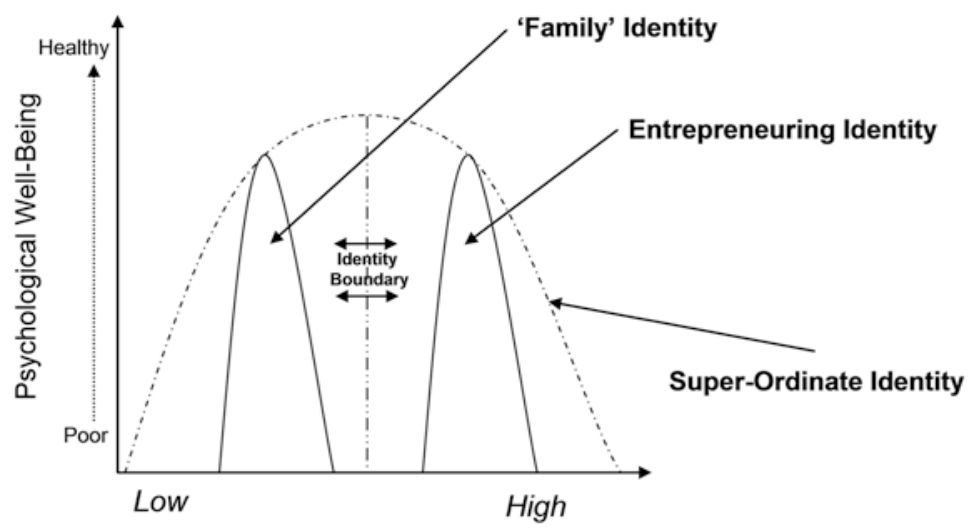

Distinctiveness

Fig. 5.3 Compartmentalization of micro-identities

curves representing two identities (refer to Fig. 5.3 (Shepherd and Haynie 2009a)). On the far right is the entrepreneurial identity curve, which confers distinctiveness while the person participates in founding activities. On the left is the non-work curve, which confers belonging while he or she participates in activities not associated with work. Compartmentalizing various micro-identities allows one to develop a super-ordinate identity that maximizes his or her psychological well-being by fulfilling his or her distinctiveness needs (through the entrepreneurial identity) and his or her belongingness needs (e.g., through the identity as a father or mother, sports team member, etc.).

Yet, managing identity with the goal of reducing identity conflict through compartmentalization may be challenging for many entrepreneurs. A large research stream has focused on exploring identity conflict, particularly work-family conflict (Lobel 1991). This work has argued that efforts to maintain separate identities using compartmentalization may not work (Lobel 1991). Greenhaus and Beutell (1985), for instance, uncovered three theoretical types of conflict between work roles and family roles: (1) time-based conflict, which occurs when the amount of time needed for the identity as an entrepreneur and the identity as a father or mother is extreme or conflicting (e.g., the individual is required to be in two places at the same time); (2) strain-based conflict, which occurs when the strain (e.g., fatigue or illnesses) caused by the stresses of one role makes it harder to adequately execute the other role; and (3) behavior-based 
conflict, which occurs when the behavior required is different between identities. For instance, the strain associated with the uncertainty of founding activities may make it challenging for an individual to successfully immerse him- or herself in the father/mother identity.

While compartmentalization is at one end of the identity-management strategies continuum, integration is at the other end. Integration is a strategy entrepreneurs use to manage multiple micro-identities and in doing so lessen the tradeoff between addressing the needs to be distinct and to belong by uniting the identity-conferring distinctiveness and an identityconferring belonging. With this strategy, both identities can be enacted (almost) simultaneously through transitioning frequently. Integration is an effort to combine identities into "a single, all-purpose mentality, one way of being, one amorphous self" (Nippert-Eng 1996: 568). A straightforward example of an integrated identity can be found in a family firm. In a family business, the roles characterized by one's micro-identities-which are very prominent in the strategy of compartmentalization-are in essence merged together when one utilizes an integration strategy. The goal of integration is to overcome the conflicting demands associated with multiple micro-identities by enacting various identities at the same time or by quickly switching between them. In Fig. 5.4, my (Dean) colleague and I (Shepherd and Haynie 2009a) illustrate this strategy, with two different identities being replaced by one identity.

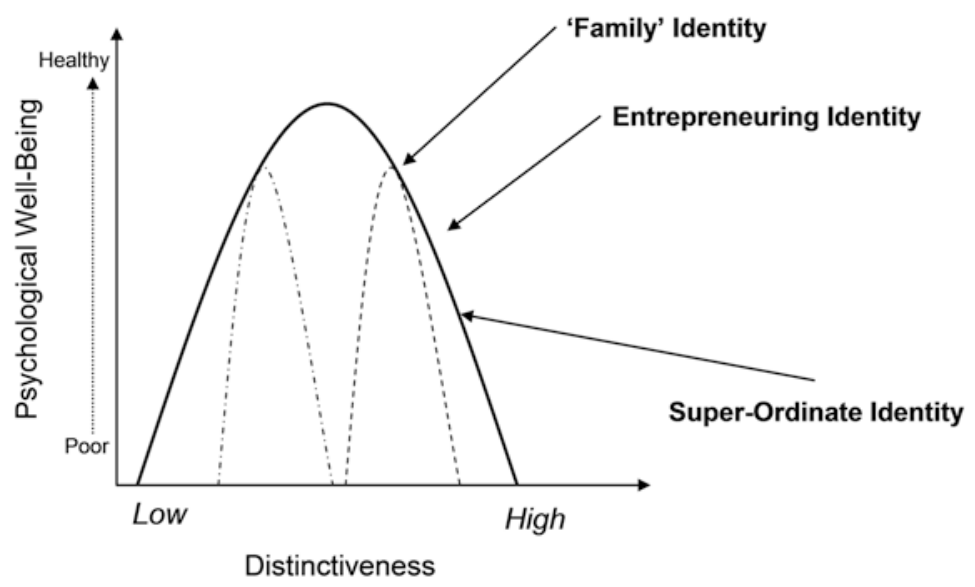

Fig. 5.4 Integration of micro-identities 
Similar to compartmentalization, entrepreneurs may have a hard time employing integration strategies to manage several identities. Attempts to lessen separation between micro-identities may lead to unforeseen interruptions of one micro-identity because of another. Such interactions can be a way to minimize the tradeoff between being distinct and belonging; however, they may also be a source of distraction. Further, these distractions may occur without warning (Hall 2002), leading to an interruption of the individual's immersion in a particular identity. For instance, a friend's phone call can interrupt one's immersion in his or her entrepreneurial micro-identity, and a call from a coworker can interrupt one's immersion in an interaction with friends. In each of these instances, the entrepreneur may have decreased psychological well-being due to feelings that neither the need for distinction nor the need for belonging is being adequately fulfilled as well as bewilderment and worry about which identity is the one that is most important (Ashforth et al. 2000). With compartmentalization strategies, where individuals maintain their separate identities, these types of interruptions are unlikely.

With the above descriptions of compartmentalization and integration strategies, it is critical to note that we are not suggesting that the extreme form of such a strategy is usual or suitable. We just propose that these strategies are endpoints on a continuum on which people allocate themselves as either following more compartmentalization or more integration when managing multiple micro-identities. Moreover, because of the different benefits and costs for compartmentalization and integration, it is likely that entrepreneurs differ in their evaluations for strategies to manage identities based on fulfilling their personal distinctiveness and belongingness needs. Indeed, individuals may have power over the degree to which they pursue strategies for being distinctive and/or to belong. Researchers usually assert that enacting an entrepreneur identity will more likely meet one's need for distinctiveness, whereas enacting other "collective" micro-identities will more likely meet one's belonging need. Some individuals will favor more compartmentalization (i.e., they prefer the benefits of compartmentalization more than those of integration or may be better positioned to handle the challenges associated with compartmentalization), whereas some individuals may favor higher integration for similar reasons. My (Dean) colleague and I (Shepherd and Haynie 2009a) argued that despite entrepreneurs' preference for either compartmentalization or integration, they all usually want to (1) fulfill their needs for being distinct and to belong, (2) reduce issues in identity transition 
related to "the effort required to become psychologically and physically disengaged from one identity and re-engaged in another identity" (adapted from Ashforth et al. 2000: 473), and (3) lessen the occurrence and scale of identity conflict.

To apply this idea of compartmentalization and integration to entrepreneurs as they attempt to balance distinctiveness and belonging, we now explore how boundaries and synergies between identities influence the degree to which compartmentalization and integration are suitable strategies for balancing entrepreneurs' needs to be distinct and to belong. We form our theorizing based on the idea that boundaries and potential synergies between micro-identities constitute strategic constraints, which is in line with the socially constructed nature of identities (Ashforth et al. 2000). Following this line of arguments, identity is not exclusively controlled by a person; rather, the individual "takes" the role characteristics that other people "offer" (Katz and Kahn 1978). Yet, our arguments do not depend on this assumption but instead imply that, for instance, entrepreneurs can strengthen or weaken identity boundaries. In other words, identities can be the outcome of negotiation (Swann 1987) wherein social reality not only shapes people (Turner 1987) but individuals also influence social reality (McNulty and Swann 1994). For instance, people utilize things like impression management and partner choice to bring others to view them as they view themselves (Swann 2005).

\section{Identity Boundaries, Identity Synergies, and Management Strategy}

Above, we outlined a continuum of strategies for managing identities by explaining the anchors of that continuum-compartmentalization and integration. The key question becomes why would (or should) an individual choose any strategy (more compartmentalized vs. more integrated) as the more suitable way to balance distinctiveness and belonging. We suggest that the success of an entrepreneur's chosen strategy in terms of maximizing well-being is dependent on the dual consideration of potential synergies between micro-identities that are in conflict (possible benefits from identity transitions). Moreover, this success also depends on the characteristic of the identities' boundaries (costs associated with identity transitions). Figure 5.5 develops and illustrates this model (Shepherd and Haynie 2009a). 


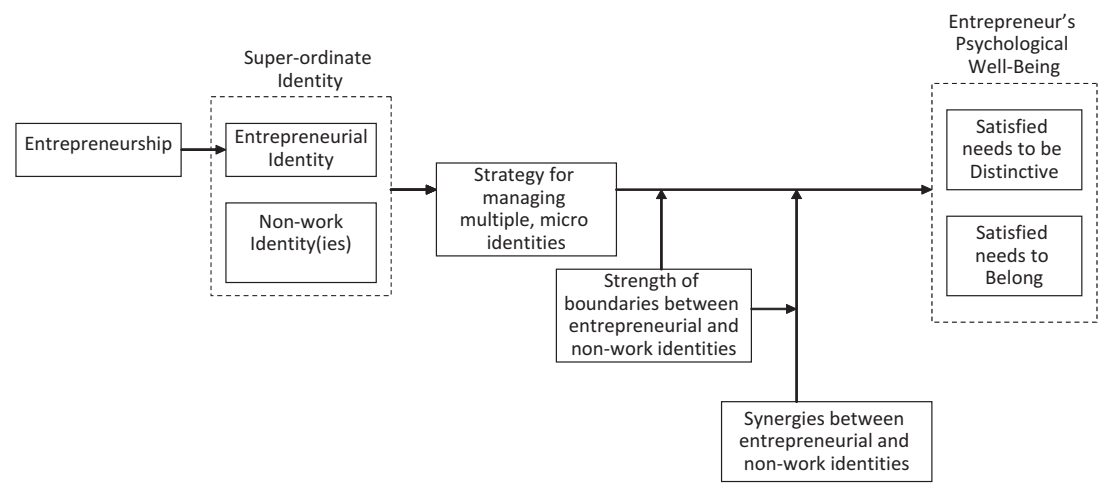

Fig. 5.5 Managing entrepreneurs' multiple micro-identities to maximize PWB

Specifically, identity synergy denotes the degree of relatedness among identities, with higher levels of convergence between identities resulting in a higher likelihood that each identity will improve the success of the other. As an example, Pratt and Foreman (2000) described a person with strong religious beliefs (a strong micro-identity related to one's role in the church) deciding to work for a religious organization, thereby serving to "align one's religious and work-related identities" (Pratt and Foreman 2000: 23). Another example could be a family firm in which one's "family" micro-identity (a key element of which is being a "provider") aligns with managing the firm to feed the family. Identity synergy occurs in the case that one identity improves the outcomes of a different identity-for instance, the family identity increases the founder identity's ability to fulfill the distinctiveness need and/or the founder identity increases the family identity's ability to meet the belongingness need. For instance, identity synergy outside the family firm context is the case of Phil Knight, the founder of Nike. His identity as a University of Oregon track team member in the early 1960s combined with the desire to uphold his identity as a running community member after graduation motivated him to develop a groundbreaking running shoe. Not only did Knight's founder identity confer and fulfill his need for distinctiveness, it also furthered his identification with the running community, thus enabling him to maintain an identity that fulfilled his belongingness needs, with each identity ultimately improving the other identity's performance. 


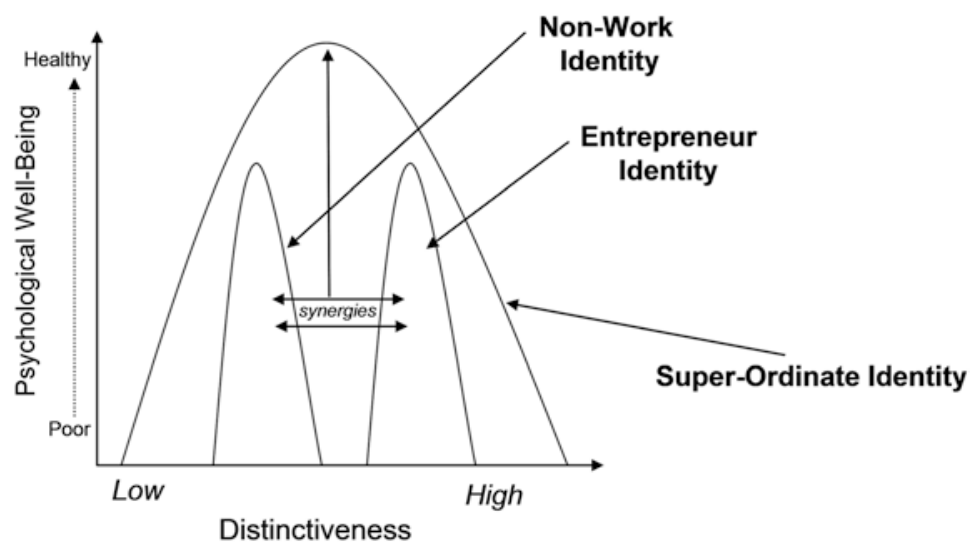

Fig. 5.6 Optimal distinctiveness and psychological well-being

The way my colleague and I (Shepherd and Haynie 2009a) conceptualized synergies' role regarding conflicting micro-identities is equivalent to how organization scholars describe the relationship between people, groups, and performance. This stream of research has shown that when synergies exist between members of a specific group, the group's overall performance will exceed the sum of each group member's individual performances (Watson et al. 1991). Along these same lines, we propose that at the microidentity level, synergies between identities both "broaden" and "raise" the super-ordinate identity curve. That is, when there are synergies between an individual's micro-identities, the benefits for the founder's holistic identity are greater than the sum of each identity's benefits. The benefits in this case are improved psychological well-being due to fulfilling both the distinctiveness and belongingness needs. We illustrate this idea in Fig. 5.6.

Next, we characterize the boundaries defining entrepreneurs' microidentities as being either strong or weak. When boundaries are strong they are impermeable and inflexible whereas weak boundaries are permeable and flexible. This boundary flexibility denotes the degree to which one's identities are associated with distinct contexts or situations. Boundary permeability describes how vulnerable a boundary is being interrupted and distracted, which makes it necessary that the individual transitions between identities. Impermeable boundaries permit only few intrusions 
into a specific identity from a different identity's roles and activities, whereas permeable boundaries are more vulnerable to intrusions. Inflexible boundaries that are rigid serve for the definition of a particular microidentity in terms of its identity-specific features, such as working hours, places, interactions, and even personality traits. For instance, an entrepreneurial identity tied to having to be in the office from 7:00 a.m. to 6:00 p.m. is an inflexible boundary. Boundaries that are flexible, on the other hand, are characterized by transitions between competing microidentities that are not well-defined and nuanced. With flexible boundaries, conflicting micro-identities are indistinct.

Integrating these notions of synergy and boundary into strategies for compartmentalizing and integrating identities helps form a framework of specific conditions that we can use to explore a particular strategy for entrepreneurs attempting to balance their needs for identity distinctiveness and belonging. My (Dean) colleague (Shepherd and Haynie 2009a) and I dichotomize the continuous variables of this model in Fig. 5.7 for illustrative purposes.

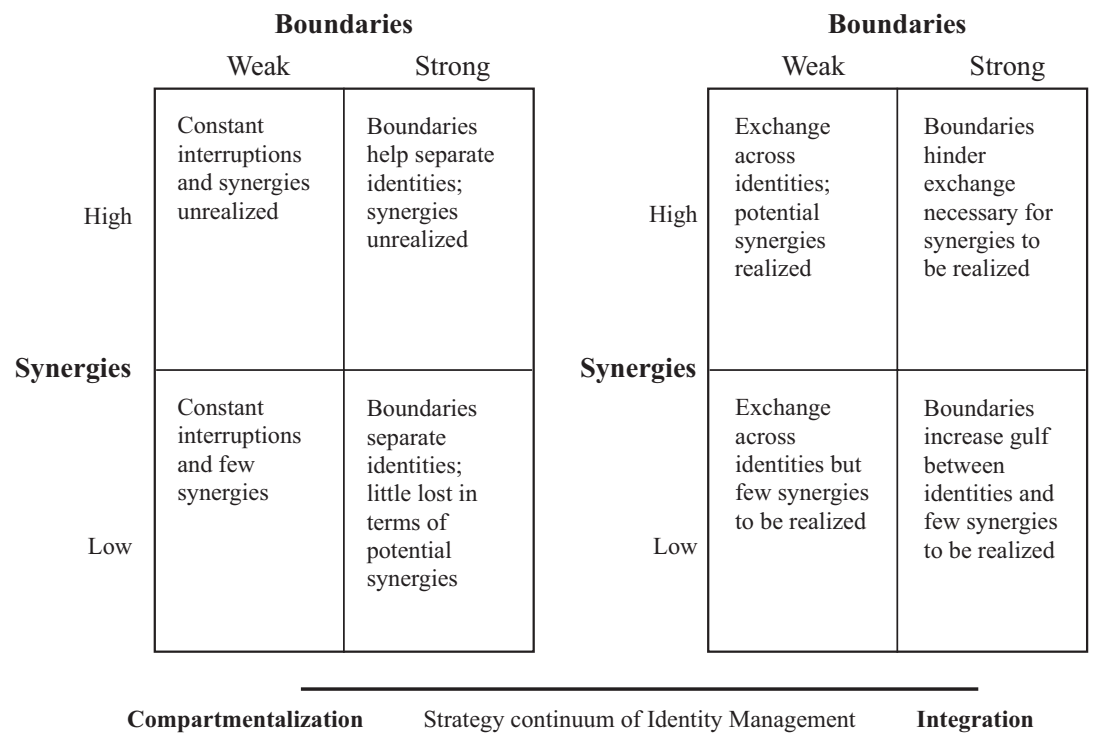

Fig. 5.7 Managing multiple identities 


\section{Compartmentalization of Micro-Identities}

The most effective compartmentalization strategies have strong boundaries. Strong boundaries help entrepreneurs keep their identities as entrepreneurs and identities that are not related to work distinct. In other words, interruptions from one identity to another are minimal. These rare transitions between identities enable the individual to balance his or her distinctiveness and belonging needs. For instance, moving from a family identity to a founder identity at the beginning of a day fulfills a founder's need for distinctiveness, and the transition from a founder identity to that of an athlete at the end of the day fulfills his or her need to belong. Yet, trying to maintain separate identities with deliberately infrequent transitions using a compartmentalization strategy makes it challenging to establish synergies. That is, two identities need to integrate for the effective realization of synergies (Allred et al. 2005; Schweiger and Goulet 2005), so realizing potential synergies hinges on the degree to which identities interact and are coordinated (Larsson and Finkelstein 1999). Therefore, entrepreneurs who utilize compartmentalization to manage multiple micro-identities have increased psychological well-being in the case of strong boundaries between identities but have decreased psychological well-being when there are weak boundaries (Shepherd and Haynie 2009a).

\section{Integrating Micro-Identities}

Entrepreneurs use integration strategies to mitigate the tradeoff between distinctiveness and belonging by uniting their entrepreneur identity related to being distinct with their identity related to belonging such that they can enact both identities at the same time (or almost at the same time) through frequent transitions. As mentioned earlier, the benefit of this type of strategy is realizing potential identity synergies. However, for one to benefit from potential synergies using an integration strategy, there have to be weak identity boundaries. For instance, there is often a blurred line between "market" and "home" in many family firms because the family and the firm are intimately entwined (Hamilton 2006). Weak boundaries lessen the challenges and psychological efforts of moving between identities, which is a prerequisite to capitalize on synergies. With growing boundary strength, however, the gulf between one's identities is wider, thus necessitating more effort for bridging the gulf. This increased effort enhances the psychological costs that come with frequent identity transitions. As such, with increasing 
boundary strength, possible synergistic benefits will become weaker or less likely to materialize. We therefore argue that when boundaries are inflexible and impermeable, it becomes more challenging-if not entirely impossible-for an individual drawing on a strategy of integration to capture the advantages of possible synergies between a distinct identity and other identities and fulfill their need to belong. However, even when boundaries are flexible and permeable and synergies do not develop, the entrepreneur must deal with the costs associated with weak boundaries. These costs can include identity conflict resulting from blurred identity boundaries such that one identity's (e.g., the entrepreneurial identity's) roles and responsibilities spill over into another identity and vice versa (Williams and Alliger 1994) without the synergistic benefits.

Consider, for example, the integration of one's founder and parental identities at a single table that at the same time represents (or frequently transitions between being) a kitchen table (parental identity) and a boardroom table (founder identity). The weakness of the boundaries improves the integration strategy's effectiveness at managing these founder and family-related identities to balance distinctiveness and belonging. Despite Friedman's (1991) argument that family firm interests are in most cases not in full alignment (1991), some founders' non-entrepreneurial identities can improve their role as entrepreneur. For instance, Stewart (2003: 387) highlighted the crucial role of family kinship in improving entrepreneurial activities: "relatives provide a diffuse, long term source of social support that underwrites the capacity of entrepreneurs to take short term risks (Mattessich and Hill 1976)." It could be that the feeling of belonging resulting from a family identity could enhance one's entrepreneurial role by increasing the distinctiveness of the identity. Research has also highlighted some examples of synergies in which the role of entrepreneur bolsters individuals' feelings of belonging. For instance, work in a family firm could help strengthen one's marriage (Wicker and Burley 1991).

Thus, synergies can raise the psychological well-being curve more than would occur if the effects of the two micro-identities were simply added together. However, for this to happen, there has to be potential for realizing synergies due to a boundary between two micro-identities that is characterized by permeability and flexibility and a strategy to achieve integration. Configurations that involve psychological integration will not be able to yield the same fit and thus will not result in similar psychological well-being advantages. While compartmentalization can lead to a suitable "fit" in the case of boundaries with little permeability and the lack of 
synergies, this "best" configuration of compartmentalization improves well-being to a lesser extent than the "best" configuration of integration as the latter can harness potential synergies. Therefore, with high identity synergy potential, individuals who use integration to manage multiple micro-identities likely have higher psychological well-being when identity boundaries are weaker than when they are stronger (Shepherd and Haynie 2009a). Moreover, in case there are higher levels of synergies and weaker boundaries, entrepreneurs with greater identity integration have higher well-being than would result from any other blend of strategy, boundary strength, and synergy level (Shepherd and Haynie 2009a).

\section{Work Roles, Organizational IDENTIFICATION, and Disjunctive Transitions}

As discussed previously, one's vocation is central to his or her identity. In other words, individuals' answer to the question "Who Am I?" often centers on a work role: I am a teacher, a doctor, an architect, a marine, and so on. Scholars have tended to investigate the relationship between identity and career in terms of occupational socialization (Nicholson 1984), role transitions (Nicholson 1984), and the processes underlying the identity conflict and change that stems from such transitions (Ashforth 2001; Ashforth et al. 2000; Ashforth and Mael 1989). This stream of research has two common cases: a relatively stable identity conflicting with changing role expectations (Swann 1987, 2005) and an evolving notion of the self conflicting with fixed role expectations (Snyder and Swann 1978; Stryker 1987). Both cases begin an incremental identity-change process that unfolds over time and is usually presumed to be path dependentthat is, future work roles are generally presumed to be explicitly "related" to one's prior career roles (Rosenbaum 1979). Additionally, although we know that vocational identity change is a path-dependent process, there is a dearth of research on identity change in response to events that almost immediately "strip" a person of his or her closely held and valued vocational identity, thus breaking his or her career path (e.g., entrepreneurial failure). Vocational identity can be defined in terms of both work role- "a set of expectations about behavior, attitudes, and values associated with a specified position (Schlenker and Gutek 1987: 287; Stryker 1968; Cantor and Mischel 1979) —and organizational identification, "a psychological state wherein the individual perceives himself or herself to be part of a larger whole" (Rousseau 1998: 217; Dutton et al. 1994). 
One such career path-breaking event is a trauma. A trauma is a situation in which an individual is "confronted with an event or events that involved actual or threatened death or serious injury, or a threat to the physical integrity of self or others" and "the person's response involved intense fear, helplessness, or horror" (APA 1994). Traumatic events can destroy individuals' fundamental beliefs that life is benevolent and meaningful and that the self is worthy (Janoff-Bulman 1989). We have a strong understanding of how individuals cope with such events (Benight et al. 1999; Bonanno 2004), but we are only beginning to discover trauma's effects on people's vocational and entrepreneurial identities.

Unfortunately, trauma is a relatively common experience in today's increasingly global organizational environment, which is affected by war, terrorism, and discontinuous organizational change. Investigating the mechanisms underlying the transition to new roles and organizations for people who go through disjunctive transitions like those often necessitated by trauma will enable scholars to more fully understand the degree to which such individuals are able to contribute to their community's and nation's economy (Audretsch 2007).

For instance, my colleague and I (Haynie and Shepherd 2011) explored the nature of vocational identity change initiated by trauma in a sample of US soldiers and marines who were disabled while serving in Iraq and Afghanistan. This was an ideal context for investigation because the connection between identity and vocation is pervasive and purposefully developed by organizations to improve members' organizational identification. Indeed, the sociology and psychology literatures are full of studies describing how the routines, symbols, and artifacts comprising military culture have a powerful and continued influence on military personnel's identity (Budd 2007; Hale 2008; Lande 2007). However, the military essentially "forces" most individuals who are disabled from wartime injuries into career transitions, deeming them unsuitable for continued organizational membership. Individuals in the study reported that their conceptions of the self became detached from their work role and the organization they had initially identified so strongly with in a single point in time-after the gunshot or bomb blast that left them injured. One soldier described this idea: "I know that Sergeant Joshua Smith is not who I am anymore and not who my family or society needs me to be. But I'm not sure who I am now."

The study's sample included ten soldiers and marines who were disabled during combat. After being discharged from the military due to their disability, each enrolled in a vocational retraining program focused 
on entrepreneurship. The theory developed sheds light on the thoughts, emotions, and behaviors characterizing individuals who have adjusted well after a trauma-namely, those who have relatively high subjective wellbeing and have made progress toward achieving new vocational milestones. The study compared these individuals with others who adjusted less well after trauma. Based on the similarities and differences among our cases, there emerged a model explaining how vocational identity change occurs after a traumatic experience.

\section{The First Step: Identity Foundation}

Scholars have centered on investigating why-as a response to an identity threat-some people are better at creating and subsequently internalizing a new conception of the self compared to others who find completing this task difficult and/or are slow in doing so. Evidence has shown that these differences are directly related to the process of negotiating and overcoming identity conflict (e.g., Burke 1991, 2003; Ibarra 1999). As discussed earlier, because individuals generally have multiple identities (Ashforth et al. 2000; Pratt and Forman 2000), identity conflict can occur when one identity's (e.g., parent) behavioral expectations go against another identity's (e.g., business owner) behavioral expectations. Researchers have explored instances when a stable identity conflicts with changing role expectations, for example, career change (Swann 1987, 2005), marriage (Burke 2006), and divorce (Rahav and Baum 2002). Results from these studies point to an incremental identity-change process whereby new behavioral expectations are developed in response to an evolving conception of self. According to Ibarra (1999: 764), "people adapt to new roles by experimenting with provisional selves that serve as trials" for a future identity. Overall, this research stream proposes people who experience identity conflict can alter their focused attention, beliefs, and behaviors to trigger the identity-change process (Snyder and Swann 1978; Stryker 1987) or can alter others' expectations to overcome identity conflict (Swann 1987, 2005). For both approaches, the underlying assumption is that identity conflict automatically and immediately initiates identity negotiation (Burke 1991, 2003). That is, because identity is so important to psychological well-being, resolving identity conflict or ambiguity receives an individual's immediate attention (Burke 1991, 2003; Brewer 1991; Tajfel and Turner 1979a, b). 
When identity change is necessitated by trauma, however, the study mentioned above (Haynie and Shepherd 2011) provides some counterevidence to the above assumptions. More specifically, the study found that although some participants in the sample eventually employed identitybuilding activities to create a new vocational identity during the entrepreneurship training program, the process for doing so was neither automatic nor instantaneous. Individuals who go through traumatic experiences are confronted with challenges that are more urgent than identity conflict as trauma introduces threats that are more detrimental to human existence than threats to identity. Along these lines, the study found that there are generally two stages in the trauma-recovery process. In Stage 1, individuals concentrate on reconstructing their fundamental assumptions about the world and humanity. In Stage 2, they focus on rebuilding a new conception of self based on a socially situated vocational identity standard.

One of the study participants, Aaron, is a good example of this process. Aaron was a marine, and his identity was strongly tied to his work role and organization. Aaron almost died in combat when an explosive went off and pinned him under a vehicle for several hours before he was rescued. Remembering his thoughts not long after his injury, Aaron recounted the following:

I was a 23 year old cocky Marine. I was fit, tops in the Marine Corps, and then it happened. I was completely helpless, hopeless. I couldn't do anything for myself. As soon as my first injury happened my confidence was gone, and I was shattered, I doubted myself. I didn't care about life anymore. I saw the evil side of humanity, and I didn't need it-I didn't want to live anymore. It was a night and day difference. It's like I was fed up with everything and honestly came to the point where I was suicidal. I came to the point in my life where I didn't care if I lived or died.

In line with the results of trauma, Aaron's experience destroyed his basic assumptions that life is benevolent and meaningful and that he is a worthy person (Janoff-Bulman 1989). After his trauma, Aaron had to reorient himself psychologically by rebuilding those destroyed assumptions before he could engage in any form of identity negotiation or change. For theory building, we refer to this orientation as identity foundation: a set of internalized and closely held beliefs and assumptions about the world and humanity that serve as the basis for future actions that will enable the self to realize meaning and purpose. Before constructing this identity 
foundation, Aaron was unable to develop, form, or negotiate a new vocational identity. Aaron used several coping mechanisms to create a new identity foundation, some of which were problem focused-centered on overcoming the issue causing distress - and some of which were emotion focused, centered on alleviating the negative emotions stemming from the issue (for a distinction, see Folkman and Moskowitz 2004). For instance, he reported how he often overused alcohol and others drugs, and how he slept through large parts of the day. Aaron reported that his alcohol and drug use were a way to "numb myself. I didn't care. I was very reckless. There was a point in my life when I came back, and after I got get out of the hospital, I was just very reckless in my life. It was foolish and stupidI'd say it was very wrong, but that's just what happened." He also took minor useful steps toward building his new identity foundation. For instance, he began recognizing obstacles hindering him from creating a new basis for meaning and purpose in his life. In one example of such behavior, he described how he realized his friends enabled his dysfunctional behaviors: "Well, they held me back for sure. Just going out and drinking and hanging out and just cutting loose. But with that shit I wasn't going anywhere in life. Just the same stupid stuff." In addition, he started going to professional counseling. Performing these simple coping activities helped Aaron reach a foundational level of psychological subsistence, thus positioning him to begin taking steps toward negotiating a new identity. He had in no way accepted his traumatic experience, but he had adequately oriented himself to begin forming a new identity, which can be seen in the following statement:

It was a very slow transition. It wasn't like I just woke up one day, and you know I'm going to put all that stuff aside, and I'm going to turn the page and end a chapter in my life. I was unhappy with life, I was unhappy with where I was at, and I knew I was going to do the stuff that I needed to get to where I wanted to go, so I started making changes. ... I think as humans we all need to have hope. I think that's a purpose for living. I think without a purpose to live, that's self-explanatory. You've got to have a purpose to live.

Studies on trauma (Janoff-Buhlman 1992; Magwaza 1999; Solomon et al. 1997) have argued that recovering from traumatic events involves reconstructing shattered assumptions of the world and of the self to reestablish psychological balance (Janoff-Buhlman 1992). While my (Dean) 
colleague and I (Haynie and Shepherd 2011) supported this idea, the findings also showed that the onset of this reconstruction process for each assumption is sequential. More specifically, the analysis across cases showed that the process of rebuilding shattered assumptions of the world to establish an identity foundation starts before rebuilding shattered assumptions of self, thus making this process a necessary condition for vocational identity change to occur in a meaningful and positive way.

\section{Trauma, Identity Change, and Entrepreneurial Career Motivations}

Expanding on the career literature, past studies have concentrated on entrepreneurship as a career option for particular groups (e.g., individuals with disabilities, women, ethnic minorities, immigrants) that are "shut out" of or face barriers to advancement in "traditional" occupational roles (Kendall et al. 2006). For instance, self-employment often guarantees that individuals with disabilities have the job accommodations they need (Wiklund et al. 2016) as well as more flexibility for other elements of their lives (Arnold and Seekins 2002; Hagner and Davies 2002). Those who are disabled frequently show interest in entrepreneurial careers (Callahan et al. 2002) with higher self-employment rates among people with disabilities than among individuals without disabilities (Arnold and Seekins 2002; U.S. Census 2002). An entrepreneurial career may also help stigmatized inmates who face considerable problems finding salaried employment to earn their living after release from prison (Patzelt et al. 2014).

Therefore, exploring motivations for entrepreneurship among people who have lost their vocational identity due to a trauma will shed light on what factors are important in forming a new vocational identity. Overall, there are two motivations in this context: an entrepreneurial career due to perceived or real barriers to other vocations (push motivation) and an entrepreneurial career due to a desire to fulfill some psychological need (pull motivation).

Sometimes, one is pushed toward entrepreneurship due to physical limitations that he or she believes "shut the door" to certain careers. More interestingly, my (Dean) colleague and I (Haynie and Shepherd 2011) uncovered a second push motivation that manifests itself as a perceived limit to employment based on experiencing trauma, coping with trauma, and undergoing ongoing identity change. The need for autonomy is important in the process of vocational identity change following trauma. 
Aaron reported that he felt "helpless and hopeless" after being injured, and he had to depend entirely on others-doctors, nurses, friends, and family-during his physical recovery. Think about how this prolonged period of reliance on others and lack of control likely affected Aaron (and other individual in similar posttrauma situations) psychologically. Aaron and those in a similar position went from being healthy with a strong wellbeing to being entirely dependent on others for their survival. Another veteran hurt during combat summarized this push motivation toward entrepreneurship as a career option best: "After all this, I've been so dependent on everybody else for everything. I need to feel like I have a say." The career and entrepreneurship literatures have not fully explored this type of push motivation; however, it is likely to help explain whydespite substantial accessibility and accommodation improvements for individuals with disabilities in the workplace over the past decade (Batavia and Schriner 2001) - those who are disabled are more than two times as likely to be self-employed than individuals in the general public (U.S. Census 2002). The desire for autonomy and control after prolonged periods of reliance on others limits these individuals' future vocation options, shutting the door on certain vocational opportunities just like physical limitations do.

In addition to this push motivation, my (Dean) colleague and I (Haynie and Shepherd 2011) uncovered psychological needs that attract these individuals to entrepreneurship as a career. People are often pulled to entrepreneurial careers due to a fundamental need for competence as well as the need to be seen as competent by others. Our participants discussed the appeal of being seen as a person who can make something great from nothing and can provide for employees, and some talked about entrepreneurship as an opportunity to show that they have the capabilities needed to be successful.

More pertinent to trauma-induced identity change are the two pull motivations that seem to differentiate between individuals who are well adjusted (i.e., coping well with their new life outside their previous career) and those who are less well adjusted. These pull motivations include the desire for security and espoused excitement/passion over the emerging vocational identity. Security is a fundamental human need, and for individuals who have not developed an identity foundation, it appears that an entrepreneurial career can fulfill this need (Haynie and Shepherd 2011). Interestingly, while some individuals mentioned they were pulled toward entrepreneurship because of the security it offers, this pull motivation was 
practically absent among individuals who were well adjusted (Haynie and Shepherd 2011).

Another pull motivation identified was an espoused passion for entrepreneurship and its related aspects. Similar to security, this pull motivation distinguishes between individuals based on how well adjusted they are. Each of the participants who had adjusted well after their traumatic experience noted passion as being a key pull toward entrepreneurship. For welladjusted individuals, espoused passion for entrepreneurship directs their attention away from the past (i.e., their trauma) and away from the present (i.e., barriers created by their disability) such that a future orientation has formed. Instead of having a detailed plan for their life, these individuals' pull motivation enables their new identity to develop; it has not yet been fully determined. This outcome contrasts to the outcomes of less well-adjusted individuals. Individuals who have adjusted less well to their trauma are focused more on the present, and the need for securitynamely, their need to find a path that will lead them to tomorrow-is greater than the more abstract idea of an imagined future along a new path. Having no identity foundation, these individuals believe that their futures are more or less pre-determined by the outside factors, that they have no control over it. As a result, individuals who are less well adjusted often continue to feel some hopelessness, believing they are on the same path with insurmountable barriers ahead.

\section{Competence Transference}

An additional consideration in this context of trauma and entrepreneurship is the connection between the far and more recent past and the future as it relates to transference of competences-namely, taking the knowledge and competencies one learns in one context and successfully applying them in another context (e.g., entrepreneurship). The career literature frequently talks about cognitions to transfer vocational competences (e.g., knowledge, skills, and abilities) from the past to the present/future (Carless 2005; Edwards 1991; O'Reilly et al. 1991). My (Dean) colleague and I (Haynie and Shepherd 2011) uncovered two types of competence transference in our study. These types differentiated those who adjusted successfully from those who failed to adjust: (1) career competence transference, which includes applying the competencies one acquired from a previous to a burgeoning new career, and (2) coping competence transference, which includes applying the knowledge, skills, and abilities one 
developed from coping with a traumatic experience to a burgeoning new career.

For well-adjusted individuals, the data revealed the connections between the past, present, and future related to applying acquired competences to their new emerging career were readily obvious. Aaron, for instance, discussed how he learned to be disciplined in the military, and how this competence was beneficial in entrepreneurship: "And ultimately I think probably the biggest factor is discipline, because I think you have to have discipline to be able to follow through with any of it. Beyond the discipline, if you don't have discipline it's not going to happen. I would just guess that if you look at some of the most successful people, it comes down to discipline." Likewise, other well-adjusted participants had a strong tendency to link the prior skills and knowledge they learned about themselves and others when coping with their trauma to their burgeoning entrepreneurial identity and venture. For example, Aaron said that having to cope with trauma helped him realize his personal strengths: "You know what? All that shit that happened to me I would never take it back; I would never trade it. Not that I could to go through it again, but I am what I am today because of the things that happened before." In addition, my (Dean) colleague and I (Haynie and Shepherd 2011) found that rather than submissively assuming transference, well-adjusted individuals concentrated on the competences they had developed in the past and ways they could utilize those competences in the future. In order to accomplish this transfer, they thought about their prior competences in a more abstract way-namely, more structurally, more generalizably, and more portably.

In contrast, individuals who were less well adjusted (1) felt that they had learned few skills in the military that could help in their new career, suggesting instead that they had a "competence disadvantage" because of their past career experiences; (2) noted fewer skills stemming from coping with their trauma; and (3) concentrated on the surface-level mismatch between their past (in this case, being in the military and coping with trauma) and their future career.

\section{Entrepreneurship as a Means of Identity Play}

As discussed above, while people usually value their career and the associated identity, events occasionally result in the termination of that identity altogether (Ebaugh 1988; Latack and Dozier 1986; Latack et al. 1995), thus requiring such people to re-create that part of the self. Recent identity 
research has investigated identity play as a means to transition to new identities (Ibarra and Petriglieri 2010; Mainemelis and Ronson 2006; Savin-Baden 2010; Schrage 1999; Winnicott 1975) as such play liberates individuals from the constraints of behavioral consistency to explore different notions of a future self (Ibarra and Petriglieri 2010; Mainemelis and Ronson 2006).

Early research on identity play (Ibarra and Petriglieri 2010) has argued that individuals must have access to a quite safe place to experiment with potential identities (Ibarra 2004; Kets de Vries and Korotov 2007). However, an "involuntary career transition, sparked by an unexpected job loss, may not provide sufficient psychological safety to allow for identity play" (Ibarra and Petriglieri 2010: 20). More specifically, individuals who experience work-related losses (e.g., failed entrepreneurs; Shepherd 2003) frequently feel grief-the negative emotional reaction in response to losing something important-and then go through a time of liminality (Ashforth 2001) during which they "struggle to establish a 'new normal' around the changed sense of self" (Conroy and O'Leary-Kelly 2014). Such loss often threatens individuals' sense of self because they generally feel a disconnect between their current and future work identities and then have to "take stock, re-evaluate, revise, re-see, and re-judge" their work identity (Strauss 1997: 102). Although important, transitioning from one work identity to another is usually challenging because one must not only give up an old identity but also create a new one.

\section{Hitting Rock Bottom and Realizing a Lost Identity}

Losing a business can make some entrepreneurs believe that their current situation in life is quite negative. This belief often makes the entrepreneur feel that he or she has bit rock bottom. Hitting rock bottom refers to a crystallization of discontent based on the development of "associative links among a multitude of unpleasant, unsatisfactory, and otherwise negative features of one's current life situation" (Baumeister 1991: 281-282). The effect of hitting rock bottom is significant, indicating that a threshold was reached that generated "a large mass of negative features" strong enough to "undermine a person's commitment to a role, relationship, or involvement" and that unrelated reservations or negative feelings were insufficient in undermining that commitment (Baumeister 1994: 282). ${ }^{3}$ For instance, an entrepreneur may view certain negative events (e.g., missed sales forecasts, supply chain problems) as isolated events that are 
standard barriers to ultimately reaching success. After the crystallization of discontent, however, the entrepreneur may see these same events as part of a broad failure pattern that comes with his or her entrepreneurial role.

Regardless of efforts to safeguard themselves from the negative feedback associated with their life situations, entrepreneurs may begin to see "bad days turning into bad years," causing them to believe that their future will probably "contain much of the same" (Bauer et al. 2005: 1182). Hitting rock bottom in this way-because one has formed associative connections between the negative features and outcomes of their lives-triggers a number of problems (Baumeister 1994) that ultimately bring negativity to a climax such that the individual's commitment to his or her role is changed in a fundamental way. For instance, many people have recounted hitting rock bottom over dissatisfaction with religious groups (Jacobs 1984; Wright 1984), marriage (Vaughan 1990), and criminal behavior (Paternoster and Bushway 2009).

Hitting rock bottom generates an emotional crisis, or an extremely negative state that people want to escape from (Jacobs 1984; Paternoster and Bushway 2009; Vaughan 1990; Wright 1984). When this occurs, the individual will likely see his or her life in a substantially different light, radically changing his or her perspectives on roles, commitments, and relationships that make up his or her life (Baumeister 1994; Maitlis 2009). A failed entrepreneur, for instance, may need to change relationships with certain friend groups (e.g., restrict or eliminate costly activities), alter financial commitments (e.g., sell expensive homes, more to a lower-cost neighborhood), and drop certain community memberships (e.g., country club, etc.), which can dramatically affect his or her everyday life (Newman 1988). On the other hand, individuals are unlikely to hit rock bottom when they lose a job that is not highly valued or can be easily regained/replaced and when losing that job is not seen as highly threatening. In such cases, my (Dean) colleague and I (Shepherd and Williams 2018) theorized that there is no crystallization of discontent that individuals need to escape.

\section{Cognitive Deconstruction AND ESCAPING IDENTITY Loss}

Some people face the crystallization of discontent from hitting rock bottom and overcome it through cognitive deconstruction (Twenge et al. 2003). More specifically, people may try to get away from the disconnect between their present and future work identities by decreasing their 
self-awareness and meaningful thought - that is, they can put themselves in a numb state (Dixon and Baumeister 1991). Similarly, cognitive deconstruction after hitting rock bottom is a state with no emotions (Pennebaker 1989; Twenge et al. 2003) because people actively evade their emotions (Baumeister 1990; Stillman et al. 2009), and it removes meaning from awareness as well as "blots out threatening implications . . . it is a refusal of insight and a denial of implications or contexts" (Baumeister 1990: 92). A cognitive deconstructive state is different from the emotions one feels from work-related loss before hitting rock bottom. More specifically, people who are in a deconstructed state are mainly cognizant of the self and their particular situation in terms of a constricted time perspective that narrowly focuses on the present (instead of the past or future), concrete actions and sensations at a superficial level (instead of more abstract, wideranging ideas at a higher level), and proximal goals (instead of distal goals from the past or about the future) (Baumeister 1990; Twenge et al. 2003). Through cognitive deconstruction, people can avoid thoughts related to the loss of their work identity and thus avoid the negative emotions that come with that loss (see Pennebaker 1989, 1993).

While deconstructed cognition eases the difficulties associated with identity loss, maintaining this cognitive state for a prolonged period of time is challenging due to the dysfunctional behaviors that come along with this state of mind, such as disinhibition (Baumeister and Vohs 2002), passivity (i.e., avoiding responsibility or self-assessment) (Ringel 1976), lack of emotion (Williams and Broadbent 1986), and irrational (rather than meaningful) thoughts (Neuringer 1972). Therefore, periods of an emotionless state are generally disrupted by periods of high negative emotions (Baumeister 1990; Wegner et al. 1986). Such spikes in negative emotions are particularly detrimental as people are unable to accurately evaluate the consequences of extreme actions, such as self-violence (Baumeister 1988) and even suicide (Baumeister 1990). Moreover, people have limited self-regulatory resources (Muraven and Baumeister 2000), so before long, the effort required to continue a deconstructed state becomes too exhausting (Kashdan and Breen 2007; Vohs et al. 2005). In turn, this exhaustion leads to higher levels of lethargy and passivity (Baumeister 1990; Twenge et al. 2003), perceptions that time is dragging (Twenge et al. 2003), and less genuine social interactions with others (John and Gross 2004; Kashdan and Breen 2007). When one reaches this state, his or her recovery process has been suspended (or not even really started), and the person begins to experience chronic dysfunction (Baumeister 1994; McIntosh and McKeganey 2000). 


\section{RECOVERING FROM IDENTITY LOSS Through Identity Play}

Although identity loss can result in negative outcomes, a potential upside of such loss is the rare opportunity for people to reboot not only their careers (Zikic and Klehe 2006) but also their central work identity via identity play. The idea of "play" is somewhat similar to deconstructed cognition in that it offers an escape (although a very different kind of escape) from one's current reality (Csikszentmihalyi 1997). Play enables the individual to withdraw "from the reigning order and the necessities of the present and offers spaces for imagination, for creation, and for everyday creativity" (Hjorth 2005: 392; Kark 2011). Although similar to cognitive destruction in terms of enabling an escape, play provides a healthier route forward by triggering processes that will ultimately generate a new work identity that is positive (Shepherd and Williams 2018).

When people undertake identity play, they generate and engage provisional identities to determine whether they could serve as future identities (Ibarra and Petriglieri 2010). In this context, provisional identities are temporary conceptualizations of the self that must be "refined with experience" to become lasting (Ibarra 1999: 767; see also Ibarra 2004). Importantly, identity play is not directed at a goal; rather, it centers on discovery, enjoyment, and "rehearsing future possibilities" (Ibarra and Petriglieri 2010: 12; see also Csikszentmihalyi 1990; Miller 1973; SuttonSmith 2009). The identities that result from such play are "trials for possible, but not yet fully elaborated" work identities (Ibarra 2005: 3). Identity play is the best context in which to create and explore temporary conceptualizations of the self as it is contextually positioned at the threshold of one's current reality and future possibilities (Ibarra and Petriglieri 2010: 11; Petriglieri and Petriglieri 2010). At this threshold, through identity play, individuals can explore alternatives without completely committing to them in the present; instead, these alternatives signify opportunities for the future (Winnicott 1975, 2001, 2005; Schrage 1999). People are likely to be very creative when thinking about various features of a prior identity that could be applied to a new identity or when forming entirely new possible concepts of the self. For instance, a failed entrepreneur may consider how the skills and knowledge he or she gained when founding a business could be utilized in a corporate setting, take exams to apply to law school, or undertake other low-risk exploration activities. When this occurs, hitting rock bottom frees the entrepreneur to actively investigate future possibilities (Shepherd and Williams 2018). 
While identity play has a lot of potential updates, it needs to happen in a space that encourages exploring, discovering, and testing untried behaviors (Schrage 1999; Winnicott 1975, 2001, 2005). This space is not necessarily a physical place but a mindset, a mindset that is ready and willing to suspend or violate traditional rules without worrying about outcomes, such as penalties or exclusion (Glynn 1994; Van Maanen and Schein 1979), or about "strings being attached" to actions (Ibarra and Petriglieri 2010). Identity play also helps individuals move away from focusing on the past and present, thus liberating their identity from the weight and restrictions of validation in a social setting (Ibarra and Petriglieri 2010; Winnicott 1975, 2005). Unlike cognitive deconstruction, however, during identity play, the individual does not omit meaning making but instead investigates an array of potential future selves (Holzman 2009), thus facilitating identity creation and recovery (Shepherd and Williams 2018).

First, after they have hit rock bottom, people divert their focus away from the negative outcomes of identity loss in an effort to get away from the present (Jacobs 1984; Paternoster and Bushway 2009; Vaughan 1990; Wright 1984), which can help lessen negative affect (Baumeister 1994). By reducing negative emotions (Fredrickson 1998), play helps the individual escape without the constraint of a limited focus on well-rehearsed actions (e.g., identity protection or restructuring). As an escape oriented toward the future, identity play focuses on positive outcomes after hitting rock bottom that are manageable and help in creating a positive new work identity. Consider, for example, a founder whose venture has failed: he or she may escape the negative emotions caused by thinking about the failure through playing with alternative career options, concentrating on several positive future results (e.g., obtaining a secure corporate job with substantial benefits, considering jobs in non-profit organizations, etc.). This positive attention directed toward the future could be further strengthened as the entrepreneur thinks "I would have never considered and pursued these opportunities had my venture been successful."

Second, to avoid the emotional consequences of hitting rock bottom, people can move their focus away from particular aims and results to overall processes. An injured military veteran, for example, may stop concentrating on reaching a higher military rank and thinking about "what might have been" and instead begin focusing on alternative career options, such as running a small organization, engaging in a new venture with other veterans, volunteering to speak to other people facing similar setbacks, and so on. Such an escape offers a process-oriented enabling space for identity 
play (Glynn 1994; Miller 1973) centered on means instead of ends such that one's actions are circuitous and probing instead of linear and directed (Miller 1973). Due to this process focus, activities associated with identity play are not controlled by unyielding rationality or a strong desire for efficiency. Instead, these activities promote finding enjoyment in the journey and the decision process, "including intuition, emotion, and taking a leap of faith" (Ibarra and Petriglieri 2010: 13), all of which encourage creative thinking and action (Isen et al. 1987). Further, while pleasure is an important motivation for play (Ibarra and Petriglieri 2010), being present in the activity at hand may in and of itself lead to positive emotional experiences (Csikszentmihalyi 1997; Mainemelis and Ronson 2006), including enjoyment. Generating positive emotions can counteract lingering negative emotions (Fredrickson et al. 2000) and further expand one's focus and cognitive processes (Fredrickson 2001; Fredrickson and Branigan 2005), thus encouraging the imaginative formation of alternative identities from identity play (Shepherd and Williams 2018).

Third, to avoid the emotional crisis and "meaning vacuum" associated with hitting rock bottom, people can concentrate less on distal goals (or on past unreached goals, for that matter, such as those stemming from identity loss) and focus more on proximal activities (i.e., what opportunities they can envision or play with in the proximal future). As mentioned earlier, identity play includes proximal activities and actions related to testing temporary identities as possible identities, which in turn leads individuals to uncover principles and skills "that are relevant in reality beyond play" (Senge 1990: 314) (see also Miller 1973; Sutton-Smith 2009). Such play involves activities related to investigating low-risk explorative notions of future identities (Brown and Starkey 2000), an enduring process until the individual at hand finds a positive identity (that is likely provisional in nature) (Dutton et al. 2010) or an identity that at least could be positive (Maitlis 2009). For instance, after an entrepreneur loses his or her business, he or she may try numerous diverse identities, including entrepreneurship consultant or teacher, business angel, venture capital investor, employee in an entrepreneurial company, running a government agency promoting entrepreneurship, and so on, by visiting different locations and experimenting with these identities. Thus, getting away from the emotional weight triggered by the crystallization of discontent allows people like this to "play" by offering time and freedom from distal goals (e.g., for the last example, meeting conductor demands, performing at live events) to explore new identity possibilities. While the emphasis is on immediate 
trials, individuals test new notions of the self (created through play) by projecting them into the relatively near future. Without the constraints of distal goals, the failed entrepreneur can freely generate and strive for near goals, such as creating and trying on provisional identities developed through identity play.

Finally, while fantasy in a cognitively deconstructed state may be detrimental (Baumeister 1990), as part of identity play it may be very useful. Identity play "generally unfolds at the threshold between fantasy and reality, or the boundary between dreams (i.e., the possible selves in our heads) and reality (i.e., concrete possibilities available in the given world at any given time)" (Ibarra and Petriglieri 2010: 15). Thus, fantasy is insufficient for identity play as it requires flirtations across the boundary between dream and reality. Fantasy in a cognitively deconstructed state is problematic because it is free of any reality, thus making it rather ineffective in generating identity alternatives. However, when individuals play out identity fantasies, they are able to creatively explore (Brown and Starkey 2000) or flirt with ideas of a provisional future self that actually have meaning in reality, which can improve the chance of forming an identity that is positive (Shepherd and Williams 2018). For instance, the failed entrepreneur may play out his or her fantasy of working in a non-profit organization as an alternative new identity by working with a local non-profit for two weeks.

\section{Discipline Following Open Identity Play}

The association between play and the formation of a new positive work identity is likely shaped by the degree to which the cognitive process includes disciplined imagination. Disciplined imagination denotes an evaluation and selection process in which individuals introduce discipline through the "consistent application of selection criteria to trial-and-error thinking" and in which they trigger imagination through the "deliberate diversity introduced into the problem statements, thought trials, and selection criteria that comprise that thinking" (Weick 1989: 516; see also Shepherd and Williams 2018). The construction of these aspects of disciplined imaginationnamely, the problem descriptions, thought experiments, and criteria applied for evaluation and selection-likely influences a person's ability to form conceivable outcomes. The outcome is a plausible new identity that is worth additional identity refinement and validation. Without forming a suitably plausible new identity, the individual is unlikely to engage in identity 
refinement or socially validate his or her new identity and will continue to play, thus delaying recovery.

Although identity play can generate possible new work identities, before a new identity can be enacted fully, the individual will likely have to engage in finer-grained identity refinement and social validation. Individuals seem to undertake a deeper analysis of a possible identity conjecture beyond the testing involved in thought trials by assessing their new identity using internal standards of self-beliefs (Ibarra 1999; Rafaeli and Sutton 1989) and external feedback based on other people's responses to their potential implementation of the new role (Ibarra and Petriglieri 2010; Meister et al. 2014). These internal and external forms of feedback provide information about the match between the alternative identity and the role it corresponds to (Bandura 1977; Weick 1979). A gap between the new possible work identity and the individual's role when performing this work requires refinement to "close the gap." In other words, the individual has to tailor the new identity to fit the new work role (Deaux 1991; Erez and Earley 1993). Pratt et al. (2006: 248) conducted a study on physician residents and showed that identity refinement includes three forms of identity customization. Physician residents used either splinting or patching to close a large gap between identifying a new work identity and performing its corresponding role. In this context, splinting refers to "a temporary identity to use until the identity develop[s] and [becomes] stronger (and then [can] be cast aside)," and patching refers to using one identity to mask holes or deficiencies in the new identity's correlation with the new work tasks (Pratt et al. 2006). For smaller gaps (which may result from effectively employing splinting or patching), the physicians appeared to use enriching to further refine their new identity. That is, although the new identity's basic features remain identical, through enriching, one obtains a more profound, richer, and more detailed understanding of the identity (Pratt et al. 2006). Overall, these refinement mechanisms enable identity adaptation (Ibarra 1999).

In addition to the three identity customization practices just listed, gaps can also be closed, and fit can be reached by altering characteristics of the work role to align it more closely with the new identity. Wrzesniewski and Dutton (2001), for instance, revealed that people take part in job crafting to redefine and re-imagine their work roles and then more closely align those work roles with work they feel is more meaningful (at least visà-vis their identity). Returning to our previous example, a failed entrepreneur could attempt to refine his or her new identity in pedagogy by first limiting its scope. For instance, the entrepreneur could choose to limit 
him- or herself to only teaching high-potential or adult students with ambitious performance-related goals instead of taking on beginner students. Similarly, he or she could develop corporate training for executives in entrepreneurial organizations or new industries. These sorts of refining activities are likely to help individuals align their budding new identity with their desired work identity.

Further, a new identity must also be socially validated. Research has shown that identity construction involves interaction in social contexts (Ibarra 1999; Meister et al. 2014; Sveningsson and Alvesson 2003). Said differently, people can try an alternative identity and thus make identity claims in social contexts. The claims an individual makes about a new identity trigger a reaction from others-namely, this alternative identity is accepted, rejected, or renegotiated by these "others" (Conroy and O'LearyKelley 2014; Ibarra 1999). It is important to note that this validation stage follows periods of less-directed, more fluid exploration of possible identities that did not involve any (or only very minimal) social validation. For example, the failed entrepreneur from our example before may decide to explore working in various government organizations, such as the Small Business Administration. In the early stages of exploration, he or she may not share this idea with anyone. However, after realizing the idea is plausible compared to other identity options pursued during play, the entrepreneur may begin seeking social validation. The ensuring social interaction is likely to provide information about any lingering deficiencies, asymmetries, or holes in the budding new work identity and about the need for additional refinements (McNulty and Swann 1994; Meister et al. 2014).

Social interaction not only helps validate a new work identity, but it can also help an individual further refine the identity. By sharing a new identity with others, the individual not only gets feedback, but those others can also aid in coproducing a more conceivable version of the identity by supporting particular features, adding new information, and facilitating the establishment of middle ground (Boje 1991; Conroy and O'Leary-Kelly 2014; Ibarra and Barbulescu 2010; Polletta and Lee 2006). Role models are a particularly important source of social validation for an alternative work identity (Ashforth 2001; Ibarra 1999; Pratt et al. 2006). Role models display the skills, styles, and behaviors that are appropriate in a social setting, and individuals can adopt and develop these skills, styles, and behaviors as a basis for their new work identity (Ibarra 1999). For example, the failed entrepreneur who decided to work for the Small Business Administration may observe an employee who is a highly regarded mentor for new businesses. Observing 
this individual may provide the entrepreneur with an illustration of good mentoring skills and behaviors in talking to and promoting mentees, which the entrepreneur may adopt and use as a basis to build up his or her new work identity as a successful startup mentor.

When a new identity is socially validated, the individual can adopt it as a positive identity; however, when there is no social validation, the individual can either abandon it or further refine and test the identity through another validation round. For instance, the failed entrepreneur might turn to his or her instructors or role models for validation and guidance, enabling the entrepreneur to coproduce this new identity in mentoring while obtaining validation and legitimacy at the same time. Such social validation is likely to facilitate individuals' transition to a new identity and serve as a continuing source of identity reinforcement and support.

Individuals can facilitate the refinement and validation of a new identity by occasionally drawing on identity play. For example, identity play can aid in splinting to overcome a major "boundary crossing" (Pratt et al. 2006; Van Maanen and Schein 1979) between a new identity and its associated work roles. Because splinting entails using a temporary identity until the new identity becomes more robust (Pratt et al. 2006), the challenge is "finding" a temporary identity that can serve as the splint while the primary identity develops. Just as identity play can aid in generating possible new identities, it can also likely help individuals generate possible "splints" when refining a new identity. Similarly, when one undertakes refinement through patching, he or she must generate an additional identity to make up for deficiencies with the new identity (Pratt et al. 2006). Identity play can be helpful in generating this "patch." For instance, a failed entrepreneur pursuing a conventional identity as a corporate employee may experience deficiencies from a lacking entrepreneurial role. To patch these deficiencies, the entrepreneur may ask to take on project-style work in the new employee role and to lead/"own" the project. Thus, he or she would be able to choose a team and work with more autonomy within the larger corporate structure. While perhaps not ideal, these patches likely help the entrepreneur transition to the new corporate employee identity.

Identity play can even help failed entrepreneurs enrich a new identity. More specifically, through identity play, an individual can explore a new identity in perhaps more extreme contexts, which can provide more profound, richer, and more nuanced information about the new identity. An individual could play with taking on different role models, combining different role features, and/or combining and recombining various roles. 
An injured veteran, for example, may combine a more stable role of running a small business, which would have few connections to his or her former work identity, with a riskier work identity as a motivational speaker for other injured veterans or for people who have gone through hardship. By playing with the motivational speaker identity, the injured veteran will likely be exposed to others who have struggled, thus gaining a greater and deeper understanding about both the lost identity and the nuance and (possible) importance of the new identity.

Identity play can also be beneficial in helping entrepreneurs engage their social context to refine a new identity and receive social validation. For instance, other people can be involved in identity play, and through this more social form of play, rules and limits are formed and adjusted (Barrett 1998; Nachmanovitch 1990) in an interpersonal negotiation process. By "playing with others," individuals can coproduce an outcome to help refine the new identity and ultimately obtain social validation. For instance, the failed entrepreneur may engage family members (Newman 1988) and other people he or she encountered during identity play in generating new versions of a budding identity. The end result of this coproduction process could be a more nuanced version of the identity as well as higher acceptance of the new identity among new professional and/or social circles. If the audience rejects the new provisional identity (generated through identity play), the entrepreneur can re-engage in identity play to develop a new potential identity that can then be refined and socially validated.

So far, we have mainly discussed what paths entrepreneurs may take after the loss of a work identity. Now, we turn to why entrepreneurs choose one path over another and why there are likely varying levels of success among people attempting to create a new positive work identity. My (Dean) colleague and I (Shepherd and Williams 2018) argued that individuals with a stronger promotion focus are more likely to undertake identity play to escape the negative emotions stemming from identity loss-from rock bottom - than individuals with a weaker promotion focus.

\section{Identity Conflict in Family Firms and an Expedited Entrepreneurial Process}

Many businesses are run and owned by family members (Heck and Trent 1999; Rogoff and Heck 2003; Wortman 1994), which can lead to tension within both the family and the firm (Daily and Dollinger 1992; Harvey and Evans 1994; Kellermanns and Eddleston 2004). Family conflict can 
be the outcome of business issues, such as different goals related to financial targets or product/service offerings. Family conflict can also arise from seemingly routine issues such as hours of operation. In addition, business conflict may stem from family issues, including the amount of time family members are not at home, conflicts between spouses, or inattentiveness to crucial family matters. In these cases, conflicts are often directly caused by the direct and frequent interaction between family members, the family, and the firm.

Exploring the behavioral expectations that come with both the family member identity and the entrepreneurial identity is key to understanding the implications of role conflict in entrepreneurial context settings. ${ }^{4}$ In the entrepreneurial context (e.g., family businesses), the boundaries between conflicting identities are often blurred and ill defined (Danes and Olson 2003). When the roles are considered independently (e.g., family member and business owner), the behavioral expectations for each role are developed based on input from the social environment. In other words, the social environment establishes "identity standards" related to what behaviors are acceptable for particular identities (Burke 2003). Although individuals may not universally share these socially ascribed standards (and they are certainly likely to vary across cultures (Choi et al. 1997)), individuals can compare their actions and behaviors to these social categories to determine if they are acceptable for a given identity. When an individual internalizes a particular identity and then acts counter to expectations for that role, identity conflict can result.

However, a common cause of identity conflict in the context of entrepreneurship begins at the intersection of the family identity and firm identity. Thus, family business identity conflict occurs when the individual activates both his or her family identity and business identity, but acting in a way consistent with one identity concurrently necessitates behaviors that are incompatible with the other identity.

Building on identity control and social identity theory, my (Dean) colleague and I (Shepherd and Haynie 2009b) concluded that the family and business identities are combined within a meta-identity-what we termed the family business meta-identity. This family business meta-identity is a higher-level identity that delineates "who we are as family" and "who we are as a business" such that it captures these occasionally competing identities. Thus, through this meta-identity, individuals can resolve conflict where family and firm overlap. Focusing on opportunity evaluation as an activity that likely generates conflict between one's family identity and his 
or her business identity, we illustrate how the meta-identity can resolve identity conflict by employing prior solutions from other conflicts that have been similar in nature, or by changing the meta-identity (by negotiation) to mitigate new conflicts.

While we recognize that the heterogeneity of viewpoints, knowledge, and experience that lead to conflict can improve decision comprehensiveness (Bantel 1993), we also theorize on the "dark side" of conflict for family firms - namely, the notion that time periods of prolonged identity conflict can result in negative outcomes for family members' psychological health (e.g., Frone et al. 1992), family disfunction (e.g., Kinnunen and Mauno 1998), and deterioration of firm performance (e.g., Beckhard and Dyer 1983). Thus, "lingering" identity conflict can be a barrier to efficient decision making in the entrepreneurial context.

\section{IDENTITY, IDENTITY CONFLICT, AND THE ENTREPRENEURIAL Firm}

We must consider the larger context in which people work and pursue all types of human interaction in order to fully understand how they conceptualize their own identities (Burke 2003; Fiske and Taylor 1991). Theories of social identity have typically centered on the premise of social categories (Tajfel and Turner 1979a, b, 1986). Social categories are based on similarity within the group in terms of the behaviors and attributes that are ideal for the particular social group (Cantor and Mischel 1977; Fiske and Taylor 1991). For instance, when someone is described as a "business owner," it calls to mind a specific meaning and specific characteristics that describe and limit the social category of "firm owners," such as the ways those individuals behave, dress, and talk; with whom they associate; their educational level; and so on. People who share more characteristics with other members in a category will be viewed as a member of the group more quickly, consensually, and consistently (Fiske and Taylor 1991). This social categorization is crucial for groups for two main reasons: (1) social categories provide "order" in the social context, and (2) social categories situate groups within that context (Ashforth and Mael 1989; Turner 1987). In other words, social categorization enables individuals to develop an identity that is based on a social comparator (Burke 2003). However, groups generally maintain multiple identities, thus making the idea of a socially situated identity more complex than it may initially seem (Ashforth et al. 2000). 
The various identities that can represent membership in a given group when taken together tend to be associated with specific expected behaviors. These expectations are largely defined by the standards and traditions dictated by the overall social environment (Stryker and Burke 2000; Stryker and Statham 1985). Compared to non-family business, in family businesses, individuals often have to balance competing expectations regarding their behaviors for at least the family role and the entrepreneurial role. Because one's identity is characterized by expectations of behaviors for a socially attributed role (Stryker and Burke 2000), we define the family identity as the set of behavioral expectations associated with the family role (Shepherd and Haynie 2009b). Psychologists and sociologists in general contend that the family role embodies expectations about behaviors related to nurturing (Giordano 2003), protection (Goldberg et al. 1999), care giving (Lechner 1993), loyalty and commitment to the family (Knoester et al. 2007), and perceptions of collective gain/loss (Berger and Janoff-Bulman 2006). Families may outline their specific behavioral expectations in various forms, such as in a family creed or culture, which is manifest in traditions, stories, and artifacts.

In a similar way, we define the business owner identity as the set of behavioral expectations associated with the business owner role (Shepherd and Haynie 2009b). Both psychological and business perspectives generally state that the role as a business owner is associated with expectations about behaviors that yield extrinsic returns (e.g., growth, financial earnings, public recognition) (Kuratko et al. 1997), commitment to the firm and its members (Muse et al. 2005), legitimacy in a social context (Malach-Pines et al. 2005), and security and prosperity for the family (Kuratko et al. 1997). Businesses may convey their specific behavioral expectations in their mission statement and/or the firm's culture (Anderson et al. 2008).

The family and business roles in an entrepreneurial firm can mutually reinforce each other but also lead to role expectations that are conflicting. The expectations and demands from work and family often lead to such conflict, which has led many scholars to explore mechanisms to mitigate conflict between conventional work and family roles via compartmentalization (Bird et al. 1983). Unlike for traditional employment, for family business entrepreneurs, compartmentalization strategies are likely an insufficient and unsuitable mechanism to deal with or prevent conflict stemming from competing expectations related to identities of being a family member and a business owner. First, for most entrepreneurial ventures, the physical and temporal boundaries underlying effective compartmentalization are 
generally not appropriate or practical. Discussion of business matters pops up at dinner, work times have to be coordinated with kids' baseball schedules, and plans for a weekend spent with the family likely overlap with moving stock at the family firm, for example. In these types of situations, the self-regulation needed to compartmentalize these closely linked identities is likely to cause mental stress (Baumeister et al. 2000), thus resulting "in poor performance on subsequent tasks requiring self-control" (Seeley and Gardner 2003: 104).

Second, compartmentalization prevents the entrepreneur or the family firm from taking advantage of synergies between the family and business identities. These synergies could positively contribute to the performance of the family firm (Kellermanns and Eddleston 2004) and to the entrepreneur's and family members' psychological well-being (Shepherd and Haynie 2009b). Research has suggested, for instance, that systemic family influences can enhance firm success (Habbershon et al. 2003; Kellermanns and Eddleston 2004). Characteristics that are generated and strengthened through family relationships, such as trust, loyalty, and commitment, often serve the business aims as well. Additionally, the families' unique knowledge about members' specific skills, limitations, and belief systems may help family businesses more effectively implement their strategies compared to businesses that do not have such strong family involvement.

Importantly, in terms of identity conflict in entrepreneurial businesses, identity at a higher level represents the identities of family and business as well as their intersection. We take this focus because for many entrepreneurial businesses, this intersection is likely to represent a distinct case defined by the shared meaning between the family and business owner identities. The intersection of these two identities is activated and shared at the same time and regularly. We now return to identity control theory and the notion of a meta-identity to manage the family and business identities as well as the intersection between the two.

\section{A Meta-Identity Perspective on the Family Business Role IDENTITY}

Drawing on social identity theory, identity control theory (ICT) (Burke 2003 ) focuses on how one's identity influences behaviors. That is, the roles individuals take on connect themselves to the social environment and others within that environment, thus creating a socially situated identity "standard." In other words, how individuals view their identity and how 
they act are relative to a socially derived standard. The focus of ICT is on how individuals' identity and behavior connect. For instance, the teacher role is connected to students, the father role is connected to children, and interactions between these groups are assessed as being either consistent or inconsistent with a social standard. ICT diverges from other social identity theories, however, because it stresses identity change.

According to Burke (2003, see also Deaux 1992, 1993), when identities share meanings, intersect, and are activated together, there will be a hierarchy of meaning, in which identities higher in the hierarchy "control the meanings of identities lower in the hierarchy." For many entrepreneurial businesses, the family business meta-identity is a higher-level identity that not only conveys to family members "who we are as a family" and "who we are as a business" but also details the intersection of the these identities. A defined family business meta-identity can help ease identity conflicts between the (lower-level) family and business identities when the conflicts are similar to those experienced in the past. In addition, this meta-identity changes as individuals engage in "negotiating, modifying, developing, and shaping expectations through interaction” (Burke 2003). The process of role transformation unfolds when people confront environmental situations that initiate identity conflict between the competing roles of family member and business owner that are unlike past identity conflicts. Because of the negative outcomes associated with prolonged and intense periods of identity conflict, it is particularly important to delineate changes of the family business meta-identity.

\section{Family, Business, Opportunities, AND IDENTITY CONFLICT}

While many actions and tasks entrepreneurs undertake could lead to conflict between the family and business identities, identity conflict is particularly likely to arise from the important task of opportunity evaluation. Opportunity evaluation can instigate identity conflict in entrepreneurial ventures for two main reasons: (1) the task is prolonged and is a chance to pursue novel paths, thus suggesting a highly uncertain environment (Knight 1921; McMullen and Shepherd 2006), and (2) opportunity evaluation makes the entrepreneur imagine the future activities and behaviors that may be necessary to effectively take advantage of that opportunity, thus making those activities and behaviors explicit. Explicit future activities and behaviors can be compared to the current expected behaviors related to the family firm identity. 
Decisions about taking action on a particular opportunity and when to do so are vital for a growing venture's ultimate survival (Bourgeois and Eisenhardt 1988). In the end, entrepreneurship is about acting "upon the possibility that one has identified an opportunity worth pursuing" (McMullen and Shepherd 2006). Action results from the development of a belief that an opportunity for someone is actually an opportunity that the family firm can, and wants to, exploit. Thus, one must believe that pursing the potential opportunity is both desirable and feasible for the family business. When evaluating a novel opportunity, the family firm must answer questions with a joint understanding of and belief in "who we are" as a family firm. For instance, evaluating an opportunity requires the family business to determine whether "this [is] an opportunity for us," which likely often includes other questions: "Is this opportunity desirable for the family and for the firm?" "Can we successfully exploit this opportunity given our current knowledge, resources, and capabilities?"

Regarding identity conflict between the family and business identities, the opportunity-evaluation process is likely to result in either (1) an opportunity that does not generate identity conflict, or (2) an opportunity that generates identity conflict that shows similarity to prior identity conflicts, or (3) an opportunity that generates conflict without similarity to prior identity conflicts.

\section{Opportunities That Do Not Cause Identity Conflict}

Sometimes, opportunity evaluation is not associated with identity conflict because the family firm believes the opportunity aligns with both the family identity and the business identity. For instance, pursing an opportunity to develop and market a new high-quality toy for education purposes may align with the expectations associated with the role of a business owner and the role of a family member. In this case, no identity conflict develops as the expected behavior of the family member role does not hinder the entrepreneur from meeting the expectations of the firm owner role. In a similar vein, a potential opportunity could be at odds with the role expectation of both identities. An example could be the opportunity to introduce a toy that has no market (i.e., children do not want to use it) and in addition is produced cheaply and coated in toxic paint. In this case as well no identity conflict exists since opportunity exploitation would be incompatible with the expectations of the business owner role as it represents a detrimental business decision and would also be inconsistent with expectations of the family role associated with the child safety and care. 
Indeed, both decisions are likely to be quick because in the first hypothetical case, the family business can easily decide to exploit the opportunity, while in the second hypothetical case, the family business can easily choose to forego the potential opportunity.

On the other hand, when the family business perceives a potential opportunity to be consistent with one identity but inconsistent with the other, identity conflict arises. When this occurs, the conflict consumes individuals' capacity to process information, thus making the decision process slower (Weick 1990; Staw et al. 1981). Moreover, there may well be procrastination-namely, postponing a behavior that one feels is emotionally unattractive although it is cognitively important because it can lead to desirable future results (Van Eerde 2000). In case the individual experiences a new form of identity conflict, that conflict is likely to continue (i.e., not be resolved immediately). This persistent identity conflict stemming from opportunity evaluation will likely affect the family business in a negative way by causing the entrepreneur to delay the decision to abandon the opportunity search and either exploit or reject the opportunity.

\section{Opportunities That Cause Identity Conflict Similar to the Past}

The degree to which identity conflict postpones the emergence of opportunity beliefs hinges on how similar the conflict is to prior conflicts. Identity conflict triggers reference to his or her family business meta-identity, which attempts to align identities lower in the hierarchy (family and business identities) as well as reconcile their individual meanings. This meta-identity embodies the shared meaning between the family and business identities as well as their intersection. The meta-identity also captures known practices to overcome conflict based on prior incidences that caused conflict between family and business identities. Thus, the meta-identity enacts routines to compare the present conflict with prior conflicts to evaluate whether and how the conflict is similar or different from those that have been resolved in the past. When the current identity conflict is consistent with one encountered in the past, the identity conflict is considered "similar." Similar means that no matter what the source of conflict is, it is "located" at the same intersection point of the family identity and the business identity as the prior conflict to which it was compared. For instance, say a family firm assessed an opportunity that requires higher family commitment to the business in the form of more work time and weekends at the firm. This new commitment level also affects the family, requiring the children to quit their weekend sports programs, for instance. In this case, the intersection of the family and 
business identities is embodied in the conflict's nature-namely, the most suitable (for this specific family) balance of commitment to both family and business activities. If the entrepreneur faces a future opportunity that causes identity conflict over a similar matter, he or she can resolve the conflict by referencing a past solution. These past solutions to identity conflict exist as an element of the larger family business meta-identity (i.e., as content).

\section{Opportunities That Cause Conflict Dissimilar to the Past}

Individuals will not always have past experience that can be applied to mitigating identity conflict caused by a new opportunity. Every opportunity is different and carries its own uncertainty that can be a new point of intersection between the family and business identities. When a new intersection forms, the family firm's meta-identity repertoire will not include a routine that can help resolve the identity conflict. (Many new family businesses likely encounter this situation often.) To overcome this new identity conflict, the family has to alter its current family business meta-identity by changing its underlying belief of "who we are as a family business." Modifying the family business meta-identity entails role transformation, or the process of "negotiating, modifying, developing, and shaping expectations through interaction" (Burke 2003). This role transformation has to occur within existing structures of the family and through interactions between family members.

The dynamic role-transformation process takes place in a social setting and includes behaviors that align perceptions of the types of behaviors which are (or are not) suitable given the existing identity standard. The identity standard for the family firm is shaped by a shared understanding of the expected behaviors for both the family and business roles as well as for the interaction of the two. Thus, to change (i.e., modify or extend) that standard, the family must craft a new collective understanding of "who we are." Consider the earlier example when the family evaluated an opportunity that was inconsistent with their shared understanding of balancing activities related to work and family, respectively. To exploit the opportunity, the family would need to undertake role renegotiation to transform their collective understanding of the family firm identity.

The literature has validated this idea of a negotiated identity (Burke 1991, 2003). When the conflict cannot be resolved by a meta-identity's current routines (i.e., the conflict is different from prior conflicts), the meta-identity needs adaptation to include a new conception of the family 
business intersection. This adaptation leads to a change in "who we are" that then alters "who we are as a family" and "who we are as a business." An outcome of the conflict-resolution process, this transformation adds to the family business's repertoire of solutions that can be used to overcome future identity conflict. How quickly identity conflict can be resolved (and thus how quickly opportunity beliefs can be formed) depends on the overall effectiveness and efficiency of renegotiation.

\section{Conclusion}

We have argued in this chapter that an entrepreneurial career provides multiple opportunities for individuals to develop a meaningful and unique selfidentity. To overcome the cognitive and psychological challenges associated with balancing the fulfillment of the basic need to be distinct with the basic need to belong, entrepreneurs can apply integration or compartmentalization strategies to manage their work-related and non-work-related microidentities. We have also illustrated how traumatic events can disrupt one's occupational identity, and that entrepreneurship as an alternative career may help reconstruct it and in doing so help individuals recover emotionally and psychologically. Finally, we have focused on the specific case of family firm owner-managers and argued how these managers can resolve potential identity conflict from their roles as family members and business owners. The next chapter will explore the role of emotions in entrepreneurship and how they are related to entrepreneurial cognition.

\section{Notes}

1. We concentrate on the individual level in this chapter.

2. We do not provide one definition for "entrepreneurial identity" because although people are likely to share common characteristics, we also expect variation, and it is a person's idea of his or her own entrepreneurial identity that influences psychological well-being.

3. People likely have different negative features in their lives, create different associative connections between these features, and, thus, have different experiences with and timing of hitting rock bottom. Future studies can investigate individual variation in the development, nature, and timing of hitting rock bottom, especially in relation to identity loss.

4. In line with the social psychology literature, we use "identity" and "role identity" interchangeably (e.g., Burke 1991; Burke and Tully 1977; Stryker 1968; Stryker and Burke 2000). 


\section{REFERENCES}

Abrams, D., \& Hogg, M. A. (1988). Comments on the motivational status of self-esteem in social identity and intergroup discrimination. European Journal of Social Psychology, 18(4), 317-334.

Akande, A. (1994). Coping with entrepreneurial stress: Evidence from Nigeria. Journal of Small Business Management, 32(1), 83-87.

Allred, B. B., Boal, K. B., \& Holstein, W. K. (2005). Corporations as stepfamilies: A new metaphor for explaining the fate of merged and acquired companies. Academy of Management Executive, 19(3), 23-37.

American Psychiatric Association, APA. (1994). Diagnostic and statistical manual of mental disorders, fourth edition: DSM-IV. Washington, DC: APA.

Anderson, C., Spataro, S. E., \& Flynn, F. J. (2008). Personality and organizational culture as determinants of influence. Journal of Applied Psychology, 93(3), 702-710.

Arnold, N. L., \& Seekins, T. (2002). Self-employment: A process for use by vocational rehabilitation agencies. Journal of Vocational Rehabilitation, 17(2), 107-113.

Ashforth, B. (2001). Role transitions in everyday life: An identity-based perspective. Mahwah: Lawrence Erlbaum.

Ashforth, B. E., \& Mael, F. (1989). Social identity theory and the organization. Academy of Management Review, 14(1), 20-39.

Ashforth, B. E., Kreiner, G. E., \& Fugate, M. (2000). All in a day's work: Boundaries and micro role transitions. Academy of Management Review, 25(3), 472-491.

Audretsch, D. B. (2007). The entrepreneurial society. Oxford: Oxford University Press.

Baker, T., \& Nelson, R. E. (2005). Creating something from nothing: Resource construction through entrepreneurial bricolage. Administrative Science Quarterly, 50(3), 329-366.

Bandura, A. (1977). Self-efficacy: Toward a unifying theory of behavioral change. Psychological Review, 84(2), 191-215.

Bantel, K. A. (1993). Comprehensiveness of strategic planning: The importance of heterogeneity of a top team. Psychological Reports, 73(1), 35-49.

Barrett, F. J. (1998). Managing and improvising: Lessons from jazz. Career Development International, 3(7), 283-286.

Batavia, A. I., \& Schriner, K. (2001). The Americans with disabilities act as engine of social change: Models of disability and the potential of a civil rights approach. Policy Studies Journal, 29(4), 690-702.

Bauer, J. J., McAdams, D. P., \& Sakaeda, A. R. (2005). Crystallization of desire and crystallization of discontent in narratives of life-changing decisions. Journal of Personality, 73(5), 1181-1214.

Baumeister, R. F. (1988). Masochism as escape from self. Journal of Sex Research, 25(1), 28-59. 
Baumeister, R. F. (1990). Suicide as escape from self. Psychological Review, 97(1), 90. Baumeister, R. F. (1991). Meanings of life. New York: Guilford Press.

Baumeister, R. F. (1994). The crystallization of discontent in the process of major life change. In T. F. Heatherton \& J. L. Weinberger (Eds.), Can personality change? (pp. 281-297). American Psychology Association: Washington, DC.

Baumeister, R. F., \& Leary, M. R. (1995). The need to belong: Desire for interpersonal attachments as a fundamental human motivation. Psychological Bulletin, 117(3), 497.

Baumeister, R. F., \& Vohs, K. D. (2002). The pursuit of meaningfulness in life. In C. R. Snyder \& S. J. Lopez (Eds.), Handbook of positive psychology (pp. 608-618). New York: Oxford University Press.

Baumeister, R. F., Dale, K. L., \& Muraven, M. (2000). Volition and belongingness: Social movements, volition, self-esteem, and the need to belong. Self, Identity, and Social Movements, 13, 230-242.

Beckhard, R., \& Dyer, W. G. (1983). Managing change in the family firm-issues and strategies. Sloan Management Review, 24(3), 59-65.

Benight, C. C., Swift, E., Sanger, J., Smith, A., \& Zeppelin, D. (1999). Coping self-efficacy as a mediator of distress following a natural disaster. Journal of Applied Social Psychology, 29(12), 2443-2464.

Berger, A. R., \& Janoff-Buhlman, R. (2006). Costs and satisfaction in close relationships: The role of loss-gain framing. Personal Relationships, 13(1), 53-68.

Bird, G. A., Bird, G. W., \& Scruggs, M. (1983). Role-management used by husbands and wives in two-earner families. Family and Consumer Sciences Research Journal, 12(1), 63-70.

Boje, D. M. (1991). The storytelling organization: A study of story performance in an office-supply firm. Administrative Science Quarterly, 36, 106-126.

Bonanno, G. A. (2004). Loss, trauma, and human resilience: Have we underestimated the human capacity to thrive after extremely aversive events? American Psychologist, 59(1), 20-28.

Bourgeois, L. J., III, \& Eisenhardt, K. M. (1988). Strategic decision processes in high velocity environments: Four cases in the microcomputer industry. Management Science, 34(7), 816-835.

Boyd, D. P., \& Gumpert, D. E. (1983). The effects of stress on early-stage entrepreneurs. In Frontiers of entrepreneurship research (pp. 180-190). Wellesley: Babson College.

Breugst, N., \& Shepherd, D. A. (2017). If you fight with me, I'll get mad! A social model of entrepreneurial affect. Entrepreneurship Theory and Practice, 41(3), 379-418.

Breugst, N., Patzelt, H., \& Rathgeber, P. (2015). How should we divide the pie? Equity distribution and its impact on entrepreneurial teams. Journal of Business Venturing, 30(1), 66-94.

Brewer, M. B. (1991). The social self: On being the same and different at the same time. Personality and Social Psychology Bulletin, 17(5), 475-482. 
Brewer, M. B. (1993). Social identity, distinctiveness, and in-group homogeneity. Social Cognition, 11(1), 150-164.

Brewer, M. B., \& Gardner, W. (1996). Who is this "We"? Levels of collective identity and self representations. Journal of Personality and Social Psychology, $71(1), 83-93$.

Brewer, M. B., \& Pickett, C. L. (1999). Distinctiveness motives as a source of the social self. Psychology of the Social Self, 14, 71-87.

Brewer, M. B., \& Weber, J. G. (1994). Self-evaluation effects of interpersonal versus intergroup social comparison. Journal of Personality and Social Psychology, $66(2), 268-275$.

Brewer, M. B., Manzi, J. M., \& Shaw, J. S. (1993). Ingroup identification as a function of depersonalization, distinctiveness, and status. Psychological Science, $4(2), 88-92$.

Brown, A. D., \& Starkey, K. (2000). Organizational identity and learning: A psychodynamic perspective. Academy of Management Review, 25(1), 102-120.

Brown, T. E., Davidsson, P., \& Wiklund, J. (2001). An operationalization of Stevenson's conceptualization of entrepreneurship as opportunity-based firm behavior. Strategic Management Journal, 22(10), 953-968.

Bruno, A. V., McQuarrie, E. F., \& Torgrimson, C. G. (1992). The evolution of new technology ventures over 20 years: Patterns of failure, merger, and survival. Journal of Business Venturing, 7(4), 291-302.

Budd, F. (2007). US air force wingman culture: A springboard for organizational development. Organization Development Journal, 25(3), 17-22.

Burke, P. J. (1991). Identity processes and social stress. American Sociological Review, 56, 836-849.

Burke, P. J. (2003). Relationships among multiple identities. Advances in Identity Theory and Research, 195-214.

Burke, P. J. (2006). Identity change. Social Psychology Quarterly, 69(1), 81-96.

Burke, P. J., \& Tully, J. C. (1977). The measurement of role identity. Social Forces, 55(4), 881-897.

Busenitz, L. W., \& Barney, J. B. (1997). Differences between entrepreneurs and managers in large organizations: Biases and heuristics in strategic decisionmaking. Journal of Business Venturing, 12(1), 9-30.

Buttner, E. H. (1992). Entrepreneurial stress: Is it hazardous to your health? Journal of Managerial Issues, 4(2), 223-240.

Callahan, M., Shumpert, N., \& Mast, M. (2002). Self-employment, choice and self-determination. Journal of Vocational Rehabilitation, 17(2), 75-85.

Cantor, N., \& Mischel, W. (1977). Traits as prototypes: Effects on recognition memory. Journal of Personality and Social Psychology, 35(1), 38-48.

Cantor, N., \& Mischel, W. (1979). Prototypes in person perception. Advances in Experimental Social Psychology, 12, 3-52.

Cantor, N., Kemmelmeier, M., Basten, J., \& Prentice, D. A. (2002). Life task pursuit in social groups: Balancing self-exploration and social integration. Self and Identity, 1(2), 177-184. 
Carless, S. A. (2005). Person-job fit versus person-organization fit as predictors of organizational attraction and job acceptance intentions: A longitudinal study. Journal of Occupational and Organizational Psychology, 78(3), 411-429.

Choi, I., Nisbett, R. E., \& Smith, E. E. (1997). Culture, category salience, and inductive reasoning. Cognition, 65(1), 15-32.

Codol, J. P. (1984). Social differentiation and undifferentiation. In H. Tajfel (Ed.), The social dimension: Volume 1: European developments in social psychology (pp. 314-337). Cambridge: Cambridge University Press.

Codol, J. P. (1987). Comparability and incomparability between oneself and others: Means of differentiation and comparison reference points. Cahiers de Psychologie Cognitive/Current Psychology of Cognition, 7(1), 87-105.

Conroy, S. A., \& O'Leary-Kelly, A. M. (2014). Letting go and moving on: Workrelated identity loss and recovery. Academy of Management Review, 39(1), 67-87.

Cova, B., \& Svanfeldt, C. (1993). Societal innovations and the postmodern aestheticization of everyday life. International Journal of Research in Marketing, 10(3), 297-310.

Csikszentmihalyi, M. (1990). Flow. The psychology of optimal experience. New York: Harper Perennial.

Csikszentmihalyi, M. (1997). Finding flow: The psychology of engagement with everyday life. New York: Basic Books.

Daily, C. M., \& Dollinger, M. J. (1992). An empirical examination of ownership structure in family and professionally managed firms. Family Business Review, $5(2), 117-136$.

Danes, S. M., \& Olson, P. D. (2003). Women's role involvement in family businesses, business tensions, and business success. Family Business Review, 16(1), 53-68.

De Vries, M. F. K., \& Korotov, K. (2007). Creating transformational executive education programs. Academy of Management Learning \& Education, 6(3), 375-387.

Deaux, K. (1991). Social identities: Thoughts on structure and change. In R. C. Curtis (Ed.), The relational self: Theoretical convergences in psychoanalysis and social psychology (pp. 77-93). New York: Guilford.

Deaux, K. (1992). Personalizing identity and socializing self. In G. Breakwell (Ed.), Social psychology of identity and the self-concept (pp. 9-33). London: Academic.

Deaux, K. (1993). Reconstructing social identity. Personality and Social Psychology Bulletin, 19(1), 4-12.

Dixon, T. M., \& Baumeister, R. F. (1991). Escaping the self: The moderating effect of self-complexity. Personality and Social Psychology Bulletin, 17(4), 363-368.

Dutton, J. E., Dukerich, J. M., \& Harquail, C. V. (1994). Organizational images and member identification. Administrative Science Quarterly, 39(2), 239-263.

Dutton, J. E., Roberts, L. M., \& Bednar, J. (2010). Pathways for positive identity construction at work: Four types of positive identity and the building of social resources. Academy of Management Review, 35(2), 265-293. 
Ebaugh, H. R. F. (1988). Becoming an ex: The process of role exit. Chicago: University of Chicago Press.

Eden, D. (1975). Organizational membership vs self-employment: Another blow to the American dream. Organizational Behavior and Human Performance, 13(1), 79-94.

Edwards, J. R. (1991). Person-job fit: A conceptual integration, literature review, and methodological critique. International Review of Industrial/Organizational Psychology, 6, 283-357. London: Wiley.

Ensley, M. D., Carland, J. W., \& Carland, J. C. (2000). Investigating the existence of the lead entrepreneur. Journal of Small Business Management, 38(4), 59-77.

Erez \& Earley. (1993). Culture, self-identity, and work. New York: Oxford University Press.

Fiske, S. T., \& Taylor, S. E. (1991). Social cognition, McGraw-Hill series in social psychology. New York: Mcgraw-Hill Book Company.

Folkman, S., \& Moskowitz, J. T. (2004). Coping: Pitfalls and promise. Annual Review of Psychology, 55, 745-774.

Fredrickson, B. L. (1998). What good are positive emotions? Review of General Psychology, 2(3), 300.

Fredrickson, B. L. (2001). The role of positive emotions in positive psychology. American Psychologist, 56(3), 218-226.

Fredrickson, B. L., \& Branigan, C. (2005). Positive emotions broaden the scope of attention and thought-action repertoires. Cognition \& Emotion, 19(3), 313-332.

Fredrickson, B. L., Mancuso, R. A., Branigan, C., \& Tugade, M. M. (2000). The undoing effect of positive emotions. Motivation and Emotion, 24(4), 237-258.

Friedman, S. D. (1991). Sibling relationships and intergenerational succession in family firms. Family Business Review, 4(1), 3-20.

Fromkin, H. L., \& Snyder, C. R. (1980). The search for uniqueness and valuation of scarcity. In K. Gergen, M. Greenberg, \& R. Willis (Eds.), Social exchange: Advances in theory and research (pp. 57-75). New York: Plenum.

Frone, M. R., Russell, M., \& Cooper, M. L. (1992). Antecedents and outcomes of work-family conflict: Testing a model of the work-family interface. Journal of Applied Psychology, 77(1), 65.

Gecas, V. (1982). The self-concept. Annual Review of Sociology, 8(1), 1-33.

Giordano, P. C. (2003). Relationships in adolescence. Annual Review of Sociology, 29(1), 257-281.

Glynn, M. A. (1994). Effects of work task cues and play task cues on information processing, judgment, and motivation. Journal of Applied Psychology, 79 (1), 34-45.

Goldberg, S., Grusec, J. E., \& Jenkins, J. M. (1999). Confidence in protection: Arguments for a narrow definition of attachment. Journal of Family Psychology, $13(4), 475-483$.

Gramzow, R. H., \& Gaertner, L. (2005). Self-esteem and favoritism toward novel in-groups: The self as an evaluative base. Journal of Personality and Social Psychology, 88(5), 801-815. 
Greenhaus, J. H., \& Beutell, N. J. (1985). Sources of conflict between work and family roles. Academy of Management Review, 10(1), 76-88.

Greenhaus, J. H., \& Powell, G. N. (2006). When work and family are allies: A theory of work-family enrichment. Academy of Management Review, 31(1), 72-92.

Gumpert, D. E., \& Boyd, D. P. (1984). The loneliness of the small-business owner. Harvard Business Review, 62(6), 18.

Guth, W. D., \& Ginsberg, A. (1991). Guest editor's introduction: Corporate entrepreneurship. Strategic Management Journal, 7(1), 5-15.

Habbershon, T. G., Williams, M., \& MacMillan, I. C. (2003). A unified systems perspective of family firm performance. Journal of Business Venturing, 18(4), $451-465$.

Hagner, D., \& Davies, T. (2002). “Doing my own thing”: Supported self-employment for individuals with cognitive disabilities. Journal of Vocational Rehabilitation, 17(2), 65-74.

Hale, H. C. (2008). The development of British military masculinities through symbolic resources. Culture \& Psychology, 14(3), 305-332.

Hall, D. T. (2002). Careers in and out of organizations. Thousand Oaks: Sage.

Hamilton, E. (2006). Whose story is it anyway? Narrative accounts of the role of women in founding and establishing family businesses. International Small Business Journal, 24(3), 253-271.

Hannafey, F. T. (2003). Entrepreneurship and ethics: A literature review. Journal of Business Ethics, 46(2), 99-110.

Harvey, M., \& Evans, R. E. (1994). Family business and multiple levels of conflict. Family Business Review, 7(4), 331-348.

Haynie, J. M., \& Shepherd, D. (2011). Toward a theory of discontinuous career transition: Investigating career transitions necessitated by traumatic life events. Journal of Applied Psychology, 96(3), 501-524.

Heck, R. K., \& Trent, E. S. (1999). The prevalence of family business from a household sample. Family Business Review, 12(3), 209-219.

Hjorth, D. (2005). Organizational entrepreneurship: With de Certeau on creating heterotopias (or spaces for play). Journal of Management Inquiry, 14(4), 386-398.

Holzman, L. (2009). Vygotsky at work and play. London: Routledge.

Hornsey, M. J., \& Jetten, J. (2004). The individual within the group: Balancing the need to belong with the need to be different. Personality and Social Psychology Review, 8(3), 248-264.

Ibarra, H. (1999). Provisional selves: Experimenting with image and identity in professional adaptation. Administrative Science Quarterly, 44(4), 764-791.

Ibarra, H. (2004). Working identity: Unconventional strategies for reinventing your career. Harvard Business Press, 34(3), 325-374.

Ibarra, H. (2005). Identity transitions: Possible selves, liminality and the dynamics of career change (Working paper no. 31/OB). INSEAD. 
Ibarra, H., \& Barbulescu, R. (2010). Identity as narrative: Prevalence, effectiveness, and consequences of narrative identity work in macro work role transitions. Academy of Management Review, 35(1), 135-154.

Ibarra, H., \& Petriglieri, J. L. (2010). Identity work and play. Journal of Organizational Change Management, 23(1), 10-25.

Isen, A. M., Daubman, K. A., \& Nowicki, G. P. (1987). Positive affect facilitates creative problem solving. Journal of Personality and Social Psychology, 52(6), $1122-1131$.

Jacobs, J. (1984). The economy of love in religious commitment: The deconversion of women from nontraditional religious movements. Journal for the Scientific Study of Religion, 23(2), 155-171.

Jamal, M., \& Badawi, J. A. (1995). Job stress, type-a behavior and employees' well-being among Muslim immigrants in North America: A study of work force diversity. International Journal of Commerce and Management, 5(4), 6-23.

Janoff-Bulman, R. (1989). Assumptive worlds and the stress of traumatic events: Applications of the schema construct. Social Cognition, 7(2), 113-136.

Janoff-Bulman, R. (1992). Shattered assumptions: Towards a new psychology of trauma. New York: Free Press.

John, O. P., \& Gross, J. J. (2004). Healthy and unhealthy emotion regulation: Personality processes, individual differences, and lifespan development. Journal of Personality, 72(6), 1301-1334.

Kark, R. (2011). Games managers play: Play as a form of leadership development. Academy of Management Learning \& Education, 10(3), 507-527.

Kashdan, T. B., \& Breen, W. E. (2007). Materialism and diminished well-being: Experiential avoidance as a mediating mechanism. Journal of Social and Clinical Psychology, 26(5), 521-539.

Katz, D., \& Kahn, R. L. (1978). The social psychology of organizations (Vol. 2). New York: Wiley.

Kellermanns, F. W., \& Eddleston, K. A. (2004). Feuding families: When conflict does a family firm good. Entrepreneurship Theory and Practice, 28(3), 209-228.

Kendall, E., Buys, N., Charker, J., \& MacMillan, S. (2006). Self-employment: An under-utilised vocational rehabilitation strategy. Journal of Vocational Rehabilitation, 25(3), 197-205.

Kets de Vries, M. F. (1985). The dark side of entrepreneurship. Harvard Business Review, 85(6), 160-167.

Kinnunen, U., \& Mauno, S. (1998). Antecedents and outcomes of work-family conflict among employed women and men in Finland. Human Relations, 51(2), 157-177.

Klotz, A. C., Hmieleski, K. M., Bradley, B. H., \& Busenitz, L. W. (2014). New venture teams: A review of the literature and roadmap for future research. Journal of Management, 40(1), 226-255.

Knight, F. H. (1921). Risk, uncertainty and profit. Washington, DC: Beard Books. 
Knoester, C., Petts, R. J., \& Eggebeen, D. J. (2007). Commitments to fathering and the well-being and social participation of new, disadvantaged fathers. Journal of Marriage and Family, 69(4), 991-1004.

Kolvereid, L. (1996). Prediction of employment status choice intentions. Entrepreneurship: Theory and Practice, 21(1), 47-58.

Korunka, C., Frank, H., Lueger, M., \& Mugler, J. (2003). The entrepreneurial personality in the context of resources, environment, and the startup process: A configurational approach. Entrepreneurship Theory and Practice, 28(1), 23-42.

Kuratko, D. F., \& Hodgetts, R. M. (1995). Entrepreneurship: A contemporary approach. Fort Worth: Dryden Press.

Kuratko, D. F., Hornsby, J. S., \& Naffziger, D. W. (1997). An examination of owner's goals in sustaining entrepreneurship. Journal of Small Business Management, $35(1), 24-33$.

Lande, B. (2007). Breathing like a soldier: Culture incarnate. The Sociological Review, 55(s1), 95-108.

Larsson, R., \& Finkelstein, S. (1999). Integrating strategic, organizational, and human resource perspectives on mergers and acquisitions: A case survey of synergy realization. Organization Science, 10(1), 1-26.

Latack, J. C., \& Dozier, J. B. (1986). After the ax falls: Job loss as a career transition. Academy of Management Review, 11(2), 375-392.

Latack, J. C., Kinicki, A. J., \& Prussia, G. E. (1995). An integrative process model of coping with job loss. Academy of Management Review, 20(2), 311-342.

Leary, M. R. (1990). Responses to social exclusion: Social anxiety, jealousy, loneliness, depression, and low self-esteem. Journal of Social and Clinical Psychology, 9(2), 221-229.

Lechler, T. (2001). Social interaction: A determinant of entrepreneurial team venture success. Small Business Economics, 16(4), 263-278.

Lechner, V. M. (1993). Support systems and stress reduction among workers caring for dependent parents. Social Work, 38(4), 461-469.

Leonardelli, G. J., \& Brewer, M. B. (2001). Minority and majority discrimination: When and why. Journal of Experimental Social Psychology, 37(6), 468-485.

Leyens, J. P., Yzerbyt, V. Y., \& Rogier, A. (1997). Personality traits that distinguish you and me are better memorized. European Journal of Social Psychology, $27(5), 511-522$.

Lobel, S. A. (1991). Allocation of investment in work and family roles: Alternative theories and implications for research. Academy of Management Review, 16(3), 507-521.

Longenecker, J. G., McKinney, J. A., \& Moore, C. W. (1988). Egoism and independence: Entrepreneurial ethics. Organizational Dynamics, 16(3), 64-72.

Lumpkin, G. T., \& Dess, G. G. (1996). Clarifying the entrepreneurial orientation construct and linking it to performance. Academy of Management Review, $21(1), 135-172$. 
Magwaza, A. S. (1999). Assumptive world of traumatized South African adults. Journal of Social Psychology, 139(5), 622-630.

Mainemelis, C., \& Ronson, S. (2006). Ideas are born in fields of play: Towards a theory of play and creativity in organizational settings. Research in Organizational Behavior, 27, 81-131.

Maitlis, S. (2009). Who am I now? Sensemaking and identity in posttraumatic growth. In L. Morgan Roberts \& J. E. Dutton (Eds.), Exploring positive identities and organizations: Building a theoretical and research foundation (pp. 47-76). New York: Psychology Press.

Malach-Pines, A., Levy, H., Utasi, A., \& Hill, T. L. (2005). Entrepreneurs as cultural heroes: A cross-cultural, interdisciplinary perspective. Journal of Managerial Psychology, 20(6), 541-555.

Markus, H. R., \& Kitayama, S. (1991). Culture and the self: Implications for cognition, emotion, and motivation. Psychological Review, 98(2), 224-253.

Mattessich, P., \& Hill, R. (1976). Family enterprise and societal development: A theoretical assessment. Journal of Comparative Family Studies, 7(2), 147-158.

McAdams, D. P. (1985). Power, intimacy, and the life story. Homewood: Dow-Jones-Irwin.

McAdams, D. P., \& Bryant, F. B. (1987). Intimacy motivation and subjective mental health in a nationwide sample. Journal of Personality, 55(3), 395-413.

McIntosh, J., \& McKeganey, N. (2000). Addicts' narratives of recovery from drug use: Constructing a non-addict identity. Social Science \& Medicine, 50(10), $1501-1510$.

McMullen, J. S., \& Shepherd, D. A. (2006). Encouraging consensus-challenging research in universities. Journal of Management Studies, 43(8), 1643-1669.

McNulty, S. E., \& Swann, W. B., Jr. (1994). Identity negotiation in roommate relationships: The self as architect and consequence of social reality. Journal of Personality and Social Psychology, 67(6), 1012-1023.

Meister, A., Jehn, K. A., \& Thatcher, S. M. (2014). Feeling misidentified: The consequences of internal identity asymmetries for individuals at work. Academy of Management Review, 39(4), 488-512.

Miller, S. (1973). Ends, means, and galumphing: Some leitmotifs of play. American Anthropologist, 75(1), 87-98.

Muraven, M., \& Baumeister, R. F. (2000). Self-regulation and depletion of limited resources: Does self-control resemble a muscle? Psychological Bulletin, 126(2), 247-259.

Muse, L. A., Rutherford, M. W., Oswald, S. L., \& Raymond, J. E. (2005). Commitment to employees: Does it help or hinder small business performance? Small Business Economics, 24(2), 97-111.

Nachmanovitch, S. (1990). Free play: Improvisation in life and art. New York: Putnam. 
Naffziger, D. W., Hornsby, J. S., \& Kuratko, D. F. (1994). A proposed research model of entrepreneurial motivation. Entrepreneurship: Theory and Practice, $18(3), 29-43$.

Naman, J. L., \& Slevin, D. P. (1993). Entrepreneurship and the concept of fit: A model and empirical tests. Strategic Management Journal, 14(2), 137-153.

Naughton, T. J. (1987). A conceptual view of workaholism and implications for career counseling and research. Career Development Quarterly, 35(3), 180-187.

Neuringer, C. (1972). Suicide attempt and social isolation on the MAPS test. Suicide and Life-threatening Behavior, 2(3), 139-144.

Newman, K. S. (1988). Falling from grace: The experience of downward mobility in the American middle class. Free Press, 115(2), 243-267.

Nicholson, N. (1984). A theory of work role transitions. Administrative Science Quarterly, 172-191.

Nippert-Eng, C. (1996). Calendars and keys: The classification of "home" and "work". Sociological Forum, 11(3), 563-582.

Oakes, P. J., Haslam, S. A., \& Turner, J. C. (1994). Stereotypes and social reality. Oxford: Basil Blackwell.

O'Reilly, C. A., Chatman, J., \& Caldwell, D. F. (1991). People and organizational culture: A profile comparison approach to assessing person-organization fit. Academy of Management Journal, 34(3), 487-516.

Ortona, G., \& Scacciati, F. (1992). New experiments on the endowment effect. Journal of Economic Psychology, 13(2), 277-296.

Oswald, R. F., \& Suter, E. A. (2004). Heterosexist inclusion and exclusion during ritual: A "straight versus gay" comparison. Journal of Family Issues, 25(7), 881-889.

Park, B., \& Rothbart, M. (1982). Perception of outgroup homogeneity and levels of social categorization: Memory for the subordinate attributes of ingroup and outgroup members. Journal of Personality and Social Psychology, 42(6), 1051-1068.

Paternoster, R., \& Bushway, S. (2009). Desistance and the "feared self": Toward an identity theory of criminal desistance. Journal of Criminal Law and Criminology, 99, 1103-1156.

Patzelt, H., Williams, T. A., \& Shepherd, D. A. (2014). Overcoming the walls that constrain us: The role of entrepreneurship education programs in prison Academy of Management Learning \& Education, 13(4), 587-620.

Pennebaker, J. W. (1989). Confession, inhibition, and disease. Advances in Experimental Social Psychology, 22, 211-244.

Pennebaker, J. W. (1993). Putting stress into words: Health, linguistic, and therapeutic implications. Behaviour Research and Therapy, 31(6), 539-548.

Petriglieri, G., \& Petriglieri, J. L. (2010). Identity workspaces: The case of business schools. Academy of Management Learning of Education, 9(1), 44-60.

Polletta, F., \& Lee, J. (2006). Is telling stories good for democracy? Rhetoric in public deliberation after 9/11. American Sociological Review, 71(5), 699-721. 
Pratt, M. G., \& Foreman, P. O. (2000). Classifying managerial responses to multiple organizational identities. Academy of Management Review, 25(1), 18-42.

Pratt, M. G., Rockmann, K. W., \& Kaufmann, J. B. (2006). Constructing professional identity: The role of work and identity learning cycles in the customization of identity among medical residents. Academy of Management Journal, $49(2), 235-262$.

Rafaeli, A., \& Sutton, R. I. (1989). The expression of emotion in organizational life. Research in Organizational Behavior, 11(1), 1-42.

Rahav, G., \& Baum, N. (2002). Divorced women: Factors contributing to selfidentity change. Journal of Divorce \& Remarriage, 37(3-4), 41-59.

Ringel, E. (1976). The pre suicidal syndrome. Suicide and Life-threatening Behavior, 6(3), 131-149.

Rogoff, E. G., \& Heck, R. K. Z. (2003). Evolving research in entrepreneurship and family business: Recognizing family as the oxygen that feeds the fire of entrepreneurship. Journal of Business Venturing, 18(5), 559-566.

Rosenbaum, J. E. (1979). Tournament mobility: Career patterns in a corporation. Administrative Science Quarterly, 24(2), 220-241.

Rousseau, D. M. (1998). Why workers still identify with organizations. Journal of Organizational Behavior, 19(3), 217-233.

Ryan, R. M., \& Deci, E. L. (2001). On happiness and human potentials: A review of research on hedonic and eudaimonic well-being. Annual Review of Psychology, 52(1), 141-166.

Savin-Baden, M. (2010). Changelings and shape shifters? Identity play and pedagogical positioning of staff in immersive virtual worlds. London Review of Education, 8(1), 25-38.

Schlenker, J. A., \& Gutek, B. A. (1987). Effects of role loss on work-related attitudes. Journal of Applied Psychology, 72(2), 287-293.

Schrage, M. (1999). Serious play: How the world's best companies simulate to innovate. Harvard Business Press, 18(4), 247-257.

Schweiger, D. M., \& Goulet, P. K. (2005). Facilitating acquisition integration through deep-level cultural learning interventions: A longitudinal field experiment. Organization Studies, 26(10), 1477-1499.

Seeley, E. A., \& Gardner, W. L. (2003). The "selfless" and self-regulation: The role of chronic other-orientation in averting self-regulatory depletion. Self and Identity, 2(2), 103-117.

Senge, P. M. (1990). The fifth discipline: The art and practice of the learning organization. New York: Doubleday.

Shane, S. (2000). Prior knowledge and the discovery of entrepreneurial opportunities. Organization Science, 11(4), 448-469.

Shepherd, D. A. (2003). Learning from business failure: Propositions of grief recovery for the self-employed. Academy of Management Review, 28(2), 318-328. 
Shepherd, D., \& Haynie, J. M. (2009a). Birds of a feather don't always flock together: Identity management in entrepreneurship. Journal of Business Venturing, 24(4), 316-337.

Shepherd, D., \& Haynie, J. M. (2009b). Family business, identity conflict, and an expedited entrepreneurial process: A process of resolving identity conflict. Entrepreneurship Theory and Practice, 33(6), 1245-1264.

Shepherd, D., \& Williams, T. (2018). Hitting rock bottom after job loss: Bouncing back to create a new positive work identity. Academy of Management Review, $43(1)$.

Sine, W. D., Mitsuhashi, H., \& Kirsch, D. A. (2006). Revisiting burns and stalker: Formal structure and new venture performance in emerging economic sectors. Academy of Management Journal, 49(1), 121-132.

Snyder, M., \& Swann, W. B. (1978). Hypothesis-testing processes in social interaction. Journal of Personality and Social Psychology, 36(11), 1202-1212.

Solomon, Z., Iancu, I., \& Tyano, S. (1997). World assumptions following disaster. Journal of Applied Social Psychology, 27(20), 1785-1798.

Staw, B. M., Sandelands, L. E., \& Dutton, J. E. (1981). Threat rigidity effects in organizational behavior: A multilevel analysis. Administrative Science Quarterly, 26(4), 501-524.

Stewart, A. (2003). Help one another, use one another: Toward an anthropology of family business. Entrepreneurship Theory and Practice, 27(4), 383-396.

Stillman, T. F., Baumeister, R. F., Lambert, N. M., Crescioni, A. W., DeWall, C. N., \& Fincham, F. D. (2009). Alone and without purpose: Life loses meaning following social exclusion. Journal of Experimental Social Psychology, 45(4), 686-694.

Stinchcombe, A. L. (1965). Organizations and social structure. Handbook of Organizations, 44(2), 142-193.

Strauss, A. L. (1997). Mirrors and masks: The search for identity. Glencoe: Transaction Publishers.

Stryker, S. (1968). Identity salience and role performance: The relevance of symbolic interaction theory for family research. Journal of Marriage and the Family, $30,558-564$.

Stryker, S. (1987). Identity theory: Developments and extensions. In K. Yardley \& T. Honess (Eds.), Self and identity: Psychosocial perspectives (pp. 89-103). Oxford: Wiley.

Stryker, S., \& Burke, P. J. (2000). The past, present, and future of an identity theory. Social Psychology Quarterly, 63(4), 284-297.

Stryker, S., \& Statham, A. (1985). Symbolic interaction and role theory. In G. Lindzey \& E. Aronson (Eds.), Handbook of social psychology (pp. 311-378). New York: Random House.

Sutton-Smith, B. (2009). The ambiguity of play. Cambridge, MA: Harvard University Press. 
Sveningsson, S., \& Alvesson, M. (2003). Managing managerial identities: Organizational fragmentation, discourse and identity struggle. Human Relations, 56(10), 1163-1193.

Swann, W. B. (1987). Identity negotiation: Where two roads meet. Journal of Personality and Social Psychology, 53(6), 1038-1051.

Swann Jr, W. B. (2005). The self and identity negotiation. Interaction Studies, $6(1), 69-83$.

Tajfel, H. (2010). Social identity and intergroup relations. Cambridge: Cambridge University Press.

Tajfel, H., \& Turner, J. C. (1979a). An integrative theory of intergroup conflict. The Social Psychology of Intergroup Relations, 33, 33-47.

Tajfel, H., \& Turner, J. C. (1979b). An integrative theory of intergroup conflict. In The social psychology of intergroup relations. Monterey: Brooks Cole.

Tajfel, H., \& Turner, J. C. (1986). The social identity theory of intergroup behavior. In S. Worchel, \& W. G. Austin (Eds.), Psychology of intergroup relations. Chicago: Nelson, 34(3), 325-374.

Teal, E. J., \& Carroll, A. B. (1999). Moral reasoning skills: Are entrepreneurs different? Journal of Business Ethics, 19(3), 229-240.

Tice, D. M., \& Baumeister, R. F. (1990). Self-esteem, self-handicapping, and selfpresentation: The strategy of inadequate practice. Journal of Personality, 58(2), 443-464.

Turner, J. H. (1987). Toward a sociological theory of motivation. American Sociological Review, 52(1), 234-227.

Twenge, J. M., Catanese, K. R., \& Baumeister, R. F. (2003). Social exclusion and the deconstructed state: Time perception, meaninglessness, lethargy, lack of emotion, and self-awareness. Journal of Personality and Social Psychology, 85(3), 409.

U.S. Census Bureau. (2002). Census 2000 summary file. Retrieved http://factfinder. census.gov

Ucbasaran, D., Lockett, A., Wright, M., \& Westhead, P. (2003). Entrepreneurial founder teams: Factors associated with member entry and exit. Entrepreneurship Theory and Practice, 28(2), 107-128.

Ufuk, H., \& Özgen, Ö. (2001). Interaction between the business and family lives of women entrepreneurs in Turkey. Journal of Business Ethics, 31(2), 95-106.

Van Eerde, W. (2000). Procrastination: Self-regulation in initiating aversive goals. Applied Psychology, 49(3), 372-389.

Van Maanen, J. E., \& Schein, E. H. (1979). Toward a theory of organizational socialization. Research in Organizational Behavior, 1, 209-264.

Vaughan, D. (1990). Autonomy, interdependence, and social control: NASA and the space shuttle challenger. Administrative Science Quarterly, 35(2), 225-257.

Vignoles, V. L., Chryssochoou, X., \& Breakwell, G. M. (2000). The distinctiveness principle: Identity, meaning, and the bounds of cultural relativity. Personality and Social Psychology Review, 4(4), 337-354. 
Vohs, K. D., Baumeister, R. F., \& Ciarocco, N. J. (2005). Self-regulation and selfpresentation: Regulatory resource depletion impairs impression management and effortful self-presentation depletes regulatory resources. Journal of Personality and Social Psychology, 88(4), 632-657.

Watson, W. E., Michaelsen, L. K., \& Sharp, W. (1991). Member competence, group interaction, and group decision making: A longitudinal study. Journal of Applied Psychology, 76(6), 803-809.

Wegner, D. M., Vallacher, R. R., Kiersted, G. W., \& Dizadji, D. (1986). Action identification in the emergence of social behavior. Social Cognition, 4(1), $18-38$.

Weick, K. (1979). The social psychology of organizing. Reading: Addison-Wesley.

Weick, K. E. (1989). Theory construction as disciplined imagination. Academy of Management Review, 14(4), 516-531.

Weick, K. E. (1990). The vulnerable system: An analysis of the Tenerife air disaster. Journal of Management, 16(3), 571-593.

West, G. P. (2007). Collective cognition: When entrepreneurial teams, not individuals, make decisions. Entrepreneurship Theory and Practice, 31(1), 77-102.

Wicker, A. W., \& Burley, K. A. (1991). Close coupling in work-family relationships: Making and implementing decisions in a new family business and at home. Human Relations, 44(1), 77-92.

Wiklund, J., Patzelt, H., \& Dimov, D. (2016). Entrepreneurship and psychological disorders: How ADHD can be productively harnessed. Journal of Business Venturing Insights, 6, 14-20.

Williams, K. J., \& Alliger, G. M. (1994). Role stressors, mood spillover, and perceptions of work-family conflict in employed parents. Academy of Management Journal, 37(4), 837-868.

Williams, J. M., \& Broadbent, K. (1986). Autobiographical memory in suicide attempters. Journal of Abnormal Psychology, 95(2), 144.

Winnicott, D. W. (1975). Transitional objects and transitional phenomena. In D. Winnicott (Ed.), Through pediatrics to psychoanalysis (pp. 229-242). London: Karnac.

Winnicott, D. W. (2001). Playing and reality. New York: Basic Books.

Winnicott, D. W. (2005). The potential space. In Playing and reality. London: Routledge.

Wortman, M. S. (1994). Theoretical foundations for family-owned business: A conceptual and research-based paradigm. Family Business Review, 7(1), 3-27.

Wright, S. A. (1984). Post-involvement attitudes of voluntary defectors from controversial new religious movements. Journal for the Scientific Study of Religion, $23,172-182$.

Wrzesniewski, A., \& Dutton, J. E. (2001). Crafting a job: Revisioning employees as active crafters of their work. Academy of Management Review, 26(2), 179-201. 
Yip, G. S. (1982). Barriers to entry: A corporate-strategy perspective. Lexington: Lexington Books/Health and Company.

Yli-Renko, H., Autio, E., \& Sapienza, H. J. (2001). Social capital, knowledge acquisition, and knowledge exploitation in young technology-based firms. Strategic Management Journal, 22(6-7), 587-613.

Zikic, J., \& Klehe, U. C. (2006). Job loss as a blessing in disguise: The role of career exploration and career planning in predicting reemployment quality. Journal of Vocational Behavior, 69(3), 391-409.

Open Access This chapter is licensed under the terms of the Creative Commons Attribution 4.0 International License (http://creativecommons.org/licenses/ by $/ 4.0 /)$, which permits use, sharing, adaptation, distribution and reproduction in any medium or format, as long as you give appropriate credit to the original author(s) and the source, provide a link to the Creative Commons license and indicate if changes were made.

The images or other third party material in this chapter are included in the chapter's Creative Commons license, unless indicated otherwise in a credit line to the material. If material is not included in the chapter's Creative Commons license and your intended use is not permitted by statutory regulation or exceeds the permitted use, you will need to obtain permission directly from the copyright holder.

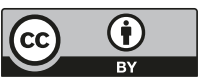

